NBER WORKING PAPER SERIES

UNINFORMATIVE FEEDBACK AND RISK TAKING:
EVIDENCE FROM RETAIL FOREX TRADING

Itzhak Ben-David

Justin Birru

Viktor Prokopenya

Working Paper 22146

http://www.nber.org/papers/w22146

NATIONAL BUREAU OF ECONOMIC RESEARCH

1050 Massachusetts Avenue

Cambridge, MA 02138

April 2016

We benefited from the comments of David Hirshleifer. We thank exp(capital) for providing the data for the project. The authors appreciate comments received from participants in seminars at Notre Dame University, The Ohio State University, and the University of Washington, as well as participants at the Behavioral Finance Conference at Erasmus University (Rotterdam). Ben-David and Birru's research was supported by the Dice Center at the Fisher College of Business. The views expressed herein are those of the authors and do not necessarily reflect the views of the National Bureau of Economic Research.

NBER working papers are circulated for discussion and comment purposes. They have not been peer-reviewed or been subject to the review by the NBER Board of Directors that accompanies official NBER publications.

(C) 2016 by Itzhak Ben-David, Justin Birru, and Viktor Prokopenya. All rights reserved. Short sections of text, not to exceed two paragraphs, may be quoted without explicit permission provided that full credit, including $(\mathcal{C}$ notice, is given to the source. 
Uninformative Feedback and Risk Taking: Evidence from Retail Forex Trading Itzhak Ben-David, Justin Birru, and Viktor Prokopenya

NBER Working Paper No. 22146

April 2016

JEL No. G02,G11,G32

\section{$\underline{\text { ABSTRACT }}$}

We document evidence consistent with retail day traders in the Forex market attributing random success to their own skill and, as a consequence, increasing risk taking. Although past performance does not predict future success for these traders, traders increase trade sizes, trade size variability, and number of trades with gains, and less with losses. There is a large discontinuity in all of these trading variables around zero past week returns: e.g., traders increase their trade size dramatically following winning weeks, relative to losing weeks. The effects are stronger for novice traders, consistent with more intense "learning" in early trading periods.

Itzhak Ben-David

Fisher College of Business

The Ohio State University

2100 Neil Avenue

Columbus, OH 43210

and NBER

bendavid@fisher.osu.edu

Justin Birru

Department of Finance

Fisher College of Business

The Ohio State University

2100 Neil Avenue

Columbus, $\mathrm{OH} 43210$

birru.2@fisher.osu.edu
Viktor Prokopenya

SBS Swiss Business School and exp(Capital)

Internatsyyanal'naya Vulitsa 36

Minsk 220030

Belarus

v@expcapital.com 


\section{$1 \quad$ Introduction}

Feedback is a key input in decision making. Information about outcomes from past actions can help improve future decision making (e.g., Seidenfeld 1985). Also, feedback is considered one of the main remedies for overconfidence: the more instances that one can observe and learn from, the better future predictions become (e.g., Arkes, Christensen, Lai, and Blumer 1987, Thaler 2000).

In certain settings, however, feedback may be uninformative, yet individuals use it to calibrate their future decisions. In particular, individuals tend to accredit observed successes to their own ingenuity and blame failures on bad luck. Langer and Roth (1975), for example, show that subjects attribute to themselves the skill of predicting the outcomes of coin tosses after a few correct guesses. The information in the feedback, therefore, can be misinterpreted and mistakenly enhance one's perception of skill, even if the outcome is impossible or hard to predict. In such cases, self-attribution of successes can lead individuals to take greater risks, based on the false conclusion of having forecasting skill. The idea that feedback may distort decision making due to self-attribution is a key component in several theoretical models. In Daniel, Hirshleifer, and Subrahmanyam (1998) and Gervais and Odean (2001), traders attribute successful investment outcomes to their skill and failures to bad luck. Over time, with some random successes, traders overestimate their ability to trade. This effect is expected to be stronger early in a traders' life. In the words of Gervais and Odean (2001), traders learn to become overconfident. Despite the compelling evidence from the lab and the theory suggesting that traders "learn" to be overconfident, there is little empirical evidence documenting this process.

In this study, we test how past trading performance is interpreted and used by individuals. The usefulness of feedback for learning and risk taking is ultimately an empirical issue that boils down to the true ability of individuals to predict outcomes and the degree of self-attribution that 
they exhibit. With this in mind, we focus on a population of day traders in the Forex (foreign exchange) market: they trade intensively (median trade lasts 16 minutes) in an environment that is very noisy and leaves very little room for skill. At the same time, traders receive immediate feedback about outcomes following their actions. Our trading dataset allows us to measure risk taking (measured as the average trade size) and perceived skill (measured as trade size variability and the number of trades) as a function of traders' past performance. If overconfidence arises through the self-attribution mechanism, as proposed by Daniel, Hirshleifer, and Subrahmanyam (1998) and Gervais and Odean (2001), ${ }^{1}$ we should be able to detect it. Our results show that past performance plays an important role in the behavior of traders, supporting the "learning to be overconfident” mechanism.

We use a dataset of individual retail accounts in the Forex futures market provided by a large international broker based in Poland. The broker caters to retail traders and specializes in foreign exchange futures. Traders use an electronic platform (dedicated software) to submit their orders and monitor their accounts. The broker lets traders leverage their equity up to 500 times, allowing ample room for risk taking. All of the traders in our dataset use a software package to submit their orders, and most are day traders who hold their positions open for only a short time. Retail trading in this market has seen large growth in recent years, perhaps because of its lotterylike nature (i.e., high leverage, short holding horizons, and quick feedback).

A key empirical challenge is to identify the effects of self-attribution (caused by overconfidence), which is the mechanism that ties current trader behavior (e.g., risk taking) to past performance. Our identification strategy is based on two non-linearities predicted by the theory

\footnotetext{
${ }^{1}$ In the words of Gervais and Odean (2001), "A trader who receives frequent, immediate, and clear feedback will, on average, peak in overconfidence early” (p. 13). Barber and Odean (2002) attribute the underperformance of online traders (as opposed to phone traders) to overconfidence, self-attribution, and the illusion of control.
} 
and distinguishes between irrational and rational learning. First, overconfident traders' responses to past gains and losses should be asymmetric. If traders exhibit self-attribution, then their behavior should be more sensitive to the magnitude of past profits in the gain domain than in the loss domain. These traders attribute past gains to their own abilities and thus strengthen their self-image as successful traders following gains. However, losses are attributed to bad luck, meaning that traders do not modify their prior beliefs about their own abilities by much. This is different from a rational Bayesian trader who will enter into short-term trades only if she knows that she has superior information. For her, the information in gains is as valuable as the information in losses; hence, she is not expected to behave differently with respect to the sign of profits. Second, traders may perceive gains, irrespective of their magnitude, as a sign of success. Thus, we should see a discontinuity in trading behavior around the origin of past performance. In other words, traders with self-attribution may respond differently to small past gains versus small past losses. In contrast, a rational Bayesian trader should display no discontinuity around zero, given that a profit that is epsilon above zero or below zero has the same informational content about the trader's skills.

In our main tests, we examine three measures of trader decision making. The first is the change in average trade size (within a week). This variable reflects the change in risk taking, as an increase in the average trade size suggests that the trader is increasing her bets. ${ }^{2}$ Our second measure of trader decision making is the change in the trader's trade size variability. It is a measure of the variability in trade sizes across the trader's transactions, with high variability reflecting a greater amount of active portfolio management. An increase in trade size variability is consistent

\footnotetext{
${ }^{2}$ Because trading accounts are likely to be a relatively small fraction of traders' wealth, the change in the average trade size that we observe cannot be driven by rebalancing.
} 
with the trader making more elaborated decisions about which positions to bet on, which should ultimately be correlated with the trader's perceived skill. The third measure is the growth in the number of trades.

We find two novel results. First, we document that the change in the current week's average trade size, the change in trade size variability, and the growth in the number of trades respond to past gains and losses in an asymmetric fashion. The past week's gains are strongly associated with higher risk taking and higher perceived skill, measured as increased average trade size and change in trade size variability, respectively. Conversely, the past week's losses have only a minimal effect on these variables. For the growth in the number of trades, the relation with losses is even negative. For all variables, we find a difference in the response slope to past performance between the positive and negative domains that is statistically and economically significant.

Second, we document a discontinuity in the average trade size, trade size variability, and the number of trades around zero past returns. When we compare small losses to small gains, we find that traders substantially increase their average trade size following small gains, but not following small losses. Similarly, trade size variability and the number of trades increase greatly following weeks of small gains, relative to weeks of small losses. That is, we see a discontinuous jump in risk taking and perceived skill exactly around zero past returns. This result is consistent with self-attribution bias: traders behave as though they perceive any gain as a positive outcome, indicating their skill. Conversely, they attribute small losses to bad luck.

The discontinuity in the changes in average trade size, trade size variability, and the number of trades is both statistically and economically significant in all specifications. In particular, the discontinuity around zero past performance accounts for about $12 \%$ to $17 \%$ of a standard deviation 
of the weekly changes in average trade size and trade size variability. The jump for the growth in the number of trades is more substantial, about $55 \%$, on average.

One potential concern is that some of the behavior we document is due to margin calls. We believe that the discontinuity tests preclude this possibility. The discontinuity in the average trade size is around zero. Even when we collapse trades into bins of average trade size of $0.02 \%$, we observe a sharp discontinuity around zero. Although some traders in our dataset are very active, one would need to make an unreasonably large number of trades per week in order for trades with an average loss of $0.02 \%$ to trigger a margin call. For instance, a trader using $\times 50$ leverage who is allowed $\times 100$ leverage would have to see a position decrease of slightly greater than $1 \%$ before getting a margin call. A $1 \%$ decrease represents a loss that is 50 times the average loss of $0.02 \%$. The average number of trades per week in our sample is 23 , and it is rare that more than a couple of these positions are open simultaneously. Also, trades are held for a very short time, making it less likely that the broker will close the position due to an adverse price movement. We conclude that margin calls are not a likely explanation of the discontinuity around zero returns.

A necessary condition for our analysis to hold is to verify our identification assumption, i.e., that current performance carries little information about future performance and is smooth with respect to past performance. We test this assumption and, indeed, do not find a meaningful differential relation between current performance and past gains versus losses that can explain the observed relationship between trader behavior and past profits. Furthermore, there is no discontinuity in future performance with respect to past gains and losses.

We conduct further analyses and isolate the first weeks of trading for each trader. According to Gervais and Odean (2001), early trading experiences disproportionately shape 
traders' perceptions of their own skill. Consistent with this prediction, we find that the effects we report are stronger in the first weeks (the first five or ten weeks) of trading.

Our study joins previous research showing that individuals often modify their behavior based on feedback and signals that contain little information. Kaustia and Knupfer (2008) and Chiang, Hirshleifer, Qian, and Sherman (2011) find supporting evidence from the IPO (initial public offerings) market, documenting that investors increase their participation in IPOs following positive returns on their previous IPO investments. Similar evidence of learning from one's past actions is documented by Malmendier and Nagel (2011), who find that investors who have experienced low stock market returns throughout their lives are more risk averse. Choi, Laibson, Madrian, and Metrick (2009) show that individuals experiencing high returns to 401(k) accounts increase their savings rates. Campbell, Ramadorai, and Ranish (2014) find evidence that investors fail to improve over time. Our paper offers novel insights into the mechanism through which individuals interpret uninformative successes, and it provides new results regarding risk taking.

The evidence presented here complements the literature about rational learning in trading. Seru, Shumway, and Stoffman (2010) find that retail traders with worse trading experiences are more likely to exit the market. Linnainmaa (2011) presents a structural model in which traders rationally learn about ability through trading, and using trading data, he shows that investors increase trade size after successful trades and exit the market after unsuccessful trades. In a study of retail traders, Nicolosi, Peng, and Zhu (2009) find that traders' future trade intensity is correlated with their past profits. Like them, we find a general correlation between trading behavior and past performance. However, the interpretation is different. Nicolosi, Peng, and Zhu (2009) interpret their results as suggesting trader rationality. In our work, we drill deeper and examine the differential sensitivity to gains versus losses separately as well as exploring the discontinuity 
around zero past performance. We show that acting in response to these dimensions is irrational as they do not predict future outcomes. Mahani and Bernhardt (2007) present a model in which rational traders learn about their skill as they trade and increase their intensity following good performance; they support their argument with empirical evidence. In our study, we present a stronger test and find that traders react to specific patterns in their past performance (gains versus losses in general, and gains versus losses around zero) that do not predict their future performance.

Finally, our study relates to the literature linking the high volume in financial markets to traders’ overconfidence. Oberlechner and Osler (2012) survey currency trades and find that traders are on average overconfident (understate uncertainty) and believe that they have above-average skill. Furthermore, they find that overconfidence does not vary with experience, and thus conclude that overconfidence survives in markets. Statman, Thorley, and Vorkink (2006) find that trading volume at the market level is positively related to lagged market returns in the United States and argue that this pattern reflects investor overconfidence and biased self-attribution. Griffin, Nardari, and Stulz (2006) study 46 markets and find that this relationship holds for many of them. Barber and Odean (2000) document that retail traders trade too often: trader performance declines with the frequency of trading. Similarly, Grinblatt and Keloharju (2009) show that traders who are more overconfident trade more often. Ben-David and Hirshleifer (2012) present evidence that the previously documented disposition effect for retail traders is a manifestation of overconfidence. Moreover, the importance of the role of feedback extends far beyond the trading context to the corporate world. Gervais, Heaton, and Odean (2011) describe how overconfidence built through self-attribution makes executives less risk averse, and Gervais and Goldstein (2007) propose that overconfidence of some team members leads to an overall increase in productivity. 


\section{$2 \quad$ Data}

\subsection{Sample}

We utilize a dataset of individual retail accounts in the Forex futures market provided by a large international broker based in Poland. The broker caters to retail traders and specializes in foreign exchange (Forex) futures. The data contain 1,118,632 transactions between September 2010 and May 2012 made by 3,103 traders. Traders send their orders electronically through dedicated software. We do not have information about the countries of residence of the traders; however, we observe their home currency: 28\% use the US Dollar, 25\% use the Euro, and 28\% use the Polish Zloty. The remainder use other Eastern European currencies.

We observe the date, time, number of contracts, underlying currency, and executed price for each buy and sell transaction. Traders in this market do not pay fixed commissions but rather pay the bid-ask spread. The spread varies over time and across currencies; it is typically 1 basis point (pips), e.g., the Euro-U.S. Dollar contract (EURUSD) can be traded at a 1.2701/1.2702 spread. We have little information about the characteristics of the traders beyond when they started their trading activity. To provide greater comfort with the analysis, we include a specification with trader fixed effects in all analyses.

The retail Forex traders in our analysis exhibit characteristics that are typical of traders in other previously studied markets, suggesting that the conclusions drawn from our sample are generalizable to other settings. For instance, the traders in our sample exhibit the disposition effect. Specifically, consistent with the behavior of professional futures traders at the Chicago Mercantile Exchange documented in Locke and Mann (2005), the traders in our sample hold losing trades for significantly longer periods of time than winning trades; the majority of trades made in our sample are profitable; and the magnitude of the average trade loss is substantially larger than the average 
trade gain. Further consistent with previous studies of retail investors, the average trader in our study does not exhibit skill. We discuss the sample of traders in more detail in Section 2.5.

Our analysis is performed at the trader-week level. We collapse our data at the weekly frequency and measure trader performance as well as trading patterns at this frequency. The choice of a week as a unit period is arbitrary. While it is possible that traders learn from their past performance, there is no reason to believe that there is a look-back unit that is common to all traders and that a week is that unit. In choosing the time unit, there is a trade-off. A short period (e.g., one hour) might be too short for updating a trader's beliefs about his or her own skill. In contrast, a long period, say a year, might be too low a frequency, as traders might update their beliefs about their own skill a few times over this period. To ensure that our results are not unique to the weekly frequency, we report the main tests for the three-day (i.e., an approximation for half a week) frequency (Internet Appendix Table A1) and two-week frequency (Internet Appendix Table A2); the main results remain the same.

\subsection{Measuring Performance}

In determining how to measure performance, we seek to best capture the signal the investor receives regarding her performance. Two possibilities emerge. First is to consider the weekly change in the trader's account balance (due to gains or losses) relative to the total amount invested over the week, which seems the most robust measure. This is equivalent to the average return per trade weighted by trade sizes (i.e., value-weighted average return per trade). The summary statistics (Table 1) show that trader-week observations are concentrated around zero past returns, with some bias toward very small negative average returns. 
A second possibility is to examine the weekly change in the account balance relative to the beginning-of-week account balance. By construction, this option incorporates the endogenous trade size decision into the return variable, thereby failing to properly reflect the signal of performance that the trader receives. To clarify this concept, imagine the case of two traders, each with the same opening balance of, say, \$100. Further assume that each trader makes a \$100 profit trading in week $t$. Trader A uses no leverage, resulting in trade sizes of $\$ 100$, but Trader B uses the maximum leverage of $\times 500$, resulting in trade sizes of $\$ 50,000$. That is, Trader $A$ makes a return that is equal to $100 \%$ of her trade size, while Trader B makes a return that is equal to $0.2 \%$ of her trade size. Calculating returns as profit divided by balance leads us to conclude that both traders have equivalent $100 \%$ returns for the week. However, it seems quite clear that Trader A, who makes $\$ 100$ profit on trades of $\$ 100$, will interpret the profit as a more positive signal of skill than will Trader $B$, who makes a $\$ 100$ profit by undertaking trades of $\$ 50,000$. For this reason, we calculate returns relative to the size of the positions that the trader is taking rather than relative to the trader's balance.

Bearing these considerations in mind, we calculate returns as total profit in a week relative to the aggregate value of all positions taken in the week. Total profit in a week also includes profit from trades that have not been closed out by the end of the week. To calculate the profit of open trades, we compare the price of the underlying currency pair as of the end of the week to the purchase price. To eliminate erroneous observations, we remove observations in which the return in the prior week is exactly zero (less than $1 \%$ of observations). 


\subsection{Measuring Risk Taking}

We also face the question of how to best measure whether traders modified their risk taking. Given that we do not observe account balances, one possibility is to measure the change in risk taking by using the change in the average trade size.

One issue with this measure is that it may be affected by additions or withdrawals from the account. We view this as a feature of our measure. The Forex accounts are likely to reflect a small part of traders' wealth. If they decide to add or withdraw funds from the trading account, it means that they decide to increase the risk in their portfolio that is related to Forex trading. This is consistent with adjusting risk taking.

A related issue is that changes in trade sizes can reflect the changes in the account balance over time. For example, a trader may decide to invest a particular fraction of her account balance. Again, this behavior indicates that the trader is willing to take a certain degree of risk related to her trading activities.

The change in average trade size is therefore measured as

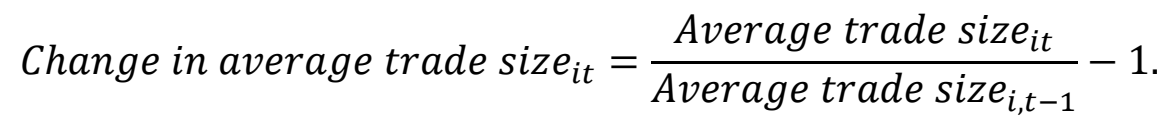

Traders who exit the sample have a change in average trade size of $-100 \%$ in the week following the week of their last trade. (In Internet Appendix Table A3, we report results of regressions that exclude these observations, and verify that this assumption does not have a material effect on the main results.) After this, traders are removed from the sample.

A possible concern is that the measure of the change in the average trade size may be more precisely estimated for traders with a greater number of trades relative to those who trade relatively 
less frequently within the week. To alleviate this concern, we use two procedures. First, we form another measure of the change in the average trade size based on the median trade size within a trader-week. Instead of using the average trade size in each week, we use the median. Second, we use a weighted least squares regression that gives greater weight to observations that are measured more precisely. We discuss this procedure in detail in Section 4.

\section{$2.4 \quad$ Measuring Perceived Skill}

We measure the perceived skill of traders as the change in trade size variability. Trade size variability may capture the extent to which a trader decides to increase or decrease trade size due to her confidence in own ability to pick winners. If a trader believes that she has signals about the profitability of trades, it is likely that these signals are of varying strength, and therefore also command varying trade sizes: e.g., when a signal is perceived as strong, a trader would increase the size of the bet. Trade size variability, therefore, reflects a combination of variability in trade signals as well as reliance of the trader on these signals. ${ }^{3}$

A concern is that trade size variability captures traders' rational reactions to true signals and therefore may reflect true skill and not just perceived skill. What differentiates true skill and perceived skill is the actual performance. Therefore, we test whether traders vary the size of their trades when they have true signals (which translate to better performance). In Table 2, we regress

\footnotetext{
${ }^{3}$ This variable could be viewed as related to the portfolio concentration discussed in the literature about mutual funds and retail investors. In general, the literature is split about the relation between portfolio concentration and performance. Some studies find that investors trade large amounts in securities in which they have superior information (e.g., mutual fund managers: Kacperczyk, Sialm, and Zheng 2005, corporate insiders trading their own industry: Ben-David, Birru, and Rossi 2015). In contrast, other studies find that high portfolio concentration is not related to performance (mutual fund managers trading own-state stocks: Pool, Stoffman, and Yonker 2012) or associated with lower performance (retail traders overweighting their own industry: Døskeland and Hvide 2011, mutual fund managers: Choi and Lou 2010).
} 
both trade size variability and the change in trade size variability on contemporaneous performance. The results show that both dependent variables are negatively correlated with the average weekly performance of traders. ${ }^{4}$ These results indicate that the change in trade size variability indeed does not reflect the true skill of traders but more likely their perceived skill.

In our data, we observe trades rather than portfolio holdings; hence, we define trade size variability for trader $i$ at time $t$ is equal to

$$
\text { Trade Size Variability }_{i t}=\sum_{j=1}^{N}\left|w_{i j t}-\bar{w}_{i t}\right| \text {, }
$$

where $N$ is the total number of trades in a given week for trader $i ; w_{i j t}$ is the relative weight of trade $j$ for trader $i$ at week $t$ (where weight is equal to the value of the trade divided by the aggregate value of all trades taken in the week); and $\bar{w}_{i t}$ is the average trade size for trader $i$ in week $t$ (equal to $1 / N$ ). We require at least two trades in a week to calculate trade size variability.

Change in trade size variability measures week-over-week changes in a trader’s perception of his or her skill. As the trader becomes more confident in his/her abilities, we expect to see trade size variability increasing as the trader makes more active decisions about dollar allocation across trades. The change in trade size variability is calculated as

$$
\text { Change in Trade Size Variability }_{i t}=\frac{\text { Trade Size Variability }_{i t}}{\text { Trade Size Variability }_{i, t-1}}-1 \text {, }
$$

where the change in trade size variability is measured as a fraction. Since the change in trade size variability has a long right tail even after winsorizing at the 99\% percentile, we winsorize it again at $200 \%$, which corresponds to the $83^{\text {rd }}$ percentile. In Internet Appendix Table A4, we verify that

\footnotetext{
${ }^{4}$ The univariate correlation of trade size variability and average returns is -0.06 ( $p<0.001$ ) and the univariate correlation of the change in trade size variability and average returns is $-0.03(\mathrm{p}<0.001)$.
} 
this choice does not drive the results: we repeat the main tests with winsorization at 5 (88 ${ }^{\text {th }}$ percentile) and $10\left(90^{\text {th }}\right.$ percentile).

Another measure of overconfidence that we use is the change in the number of trades from week $t-1$ to week $t$. Trading frequency has been used in the literature as an indicator of one's belief in his or her own skill (e.g., Barber and Odean 2000, Grinblatt and Keloharju 2009). We use the following expression for the change in the number of trades:

$$
\text { Change in the Number of Trades } \text { Trt }_{i t}=\frac{\text { Number of } \text { Trades }_{i t}}{\text { Number of Trades } \text { Trit }_{i}}-1 .
$$

\subsection{Summary Statistics}

Table 1 presents summary statistics for the sample. Panel A displays statistics at the trader level, Panel B at the trade level, and Panel C at the trader-week level. We exclude traders with fewer than 20 trades in the sample. The 3,103 active traders in the sample make a total of 1,118,632 trades. All regression variables are winsorized at $1 \%$ and $99 \%$. The average trader is in the dataset for almost exactly six months (181 days). This is the amount of time between a trader's first and last trade. About $25 \%$ of traders leave the sample within the first 46 days, while $50 \%$ of traders exit the sample within 155 days. Of the 181 days on average between open and close, traders are actively trading on an average of 50 of those days. The average trader has an equal-weighted return per trade of $-0.035 \%$, and very few traders quit while ahead. That traders have such small average returns per trade is not surprising given that the median trade is open for only 16 minutes, as can be seen from Panel B. Only 16.2\% of traders are profitable upon exiting the sample. 
In unreported results, we also document that traders appear substantially more likely to quit immediately after experiencing poor returns. For instance, the average return of a quitting trader in the week prior to quitting is $-0.1024 \%$. In contrast, the average return in week (t-1) for all nonquitting traders is $-0.0184 \%$. Additionally, $78 \%$ of the traders in the sample who quit experience negative returns in the week prior to quitting. Not surprisingly, the effects are stronger for newer traders. For traders that quit within the first five weeks of trading, $88 \%$ have experienced negative returns in the week prior to quitting.

The traders in the sample are very active. Despite the relatively short trading lives of the traders in the sample, the average trader engages in just over 341 trades. Panel B shows that traders, on average, keep trades open for very short periods of time. The average trade is open for 292 minutes, but this is heavily skewed by the right tail of trades. About $25 \%$ of trades are open for only four minutes or less, and the median trade is open for only 16 minutes. The average absolute trade size is $\$ 14,230$.

Panel C displays trader-week-level summary statistics. Again demonstrating the active nature of the traders in the sample, the average trader makes 23 trades per week. Traders are on average not profitable. ${ }^{5}$ Only $44 \%$ of weeks are profitable, and only $24 \%$ of weeks close with a trader having an aggregate running profit. This stands in contrast to the fact that $62.8 \%$ of trades are winning trades, as shown in Panel B. Traders exhibit the disposition effect, quickly realizing winning trades while only slowly realizing losing trades. The result is that the magnitude of the gain on winning trades is much smaller than the magnitude of the loss on losing trades. In unreported statistics, we find that losing trades are on average open for more than twice as long as

\footnotetext{
${ }^{5}$ Returns always use both realized and unrealized profits.
} 
winning trades and that the average loss on a losing trade is more than twice the absolute magnitude of the average gain on a winning trade.

\section{Identification and Empirical Approach}

The goal of the study is to test whether traders adjust their future risk taking and perceptions about their own skill in response to past performance. The tested claim is causal in the sense that there is an explicit proposed economic mechanism that generates the effect. Specifically, traders adjust their behavior based on past performance in an asymmetric manner: they attribute successes to their own skill but ascribe failures to bad luck. We expect this behavior to generate an asymmetric pattern with respect to past performance.

We propose two testable predictions. First, the week-on-week changes in risk taking and perceived skill may have greater sensitivity to past performance in the domain of past gains than in the domain of past losses. In other words, higher returns in the domain of past gains should encourage traders to increase their risk taking and enhance their perceptions of their own skill. In contrast, an increase in losses is expected not to have a large effect on risk taking or perceived risk, as losses are attributed to bad luck, and hence traders do not see a need to adjust their trading parameters.

To test this hypothesis, we use a piece-wise linear specification (positive versus negative) in which we measure the average slope (sensitivity) of trading behavior (risk taking or perceived risk) as a function of past performance. If traders attribute losses to bad luck, then both small losses and large losses will be attributed to bad luck and the slope in the negative domain will be relatively flat. On the other hand, if investors attribute successes to skill, then large gains will be interpreted 
as a signal of greater skill than small gains, resulting in a positive slope in the domain of gains. We predict that the slope in the positive domain will be steeper than that in the negative domain.

Our second prediction is about the discontinuity in trading behavior around the origin of past returns, as traders may simply use the binary categories of "gain” or "loss" to summarize their performance. Because traders attribute gains to their own skill and losses to bad luck, even a very small gain could trigger an increase in risk taking and enhanced perceptions of their skill. Thus, we expect to see a discontinuity in behavior around the origin of past performance.

This prediction can be tested by examining the average response of the trading behavior measures (risk taking and perceived skill) around zero for small gains and for small losses. We predict that small gains will generate a statistically larger response than will small losses. Figure 1 presents an illustration of the patterns predicted by our two hypotheses. ${ }^{6}$

Another dimension in which we expect to observe differential effects is traders' experience. According to Gervais and Odean (2001), traders adjust their behavior more when they are novices. Hence, the effects (differential slopes, discontinuity) should be stronger for early-life traders.

A necessary component in the identification proposal is that the relation between current performance and past performance does not correspond with the patterns of trading behavior that traders exhibit. While current performance can vary with past performance (e.g., if some skill exists in trading), the identification exercise will not be valid if there is a slope differential in the direction predicted (steeper slope for positive performance than for negative performance, or a

\footnotetext{
${ }^{6}$ Note that while this chart looks visually similar to the charts in Ben-David and Hirshleifer (2012) (e.g., Figure 2a), they convey different messages. The charts in Ben-David and Hirshleifer report the likelihood of selling an individual position given an unrealized loss or gain in that position. In contrast, Figure 1 here shows risk taking as a function of past realized profits from trading in the previous period. Also, the traders in Ben-David and Hirshleifer hold their positions for days and months, while the traders in the current study typically hold their positions for a few minutes or hours.
} 
discontinuity around zero past returns). We can test the relation between current and past performance using the same set of empirical specifications as in the predictions discussed above: a test for slope differences and a test for discontinuity around zero past returns.

\section{$4 \quad$ Risk Taking and Perceived Skill: Effect of Past Performance}

\subsection{Difference in Slopes between Positive and Negative Domains of Past Performance}

In Table 3, we examine how past performance affects risk taking and perceived skill. Panel A tests whether changes in risk taking and perceived skill exhibit differential responses in the positive and negative domains of past returns. Self-attribution bias suggests that traders will display increased risk taking and perceived skill in the domain of gains, while exhibiting far less sensitivity to past returns in the domain of losses. We examine this hypothesis by testing for a difference in slope in the positive and negative domain of past returns.

Panel A of Table 3 displays results from OLS regressions of the change in average trade size, the change in trade size variability, and the change in the number of trades, on returns in week $t-1$, a binary variable capturing whether the return in week $t-1$ was positive, and returns in week $t-1$ interacted with this binary variable. The interaction term coefficients in the second row capture any differences in slope in the positive and negative domains of past week returns. ${ }^{7}$ In

\footnotetext{
${ }^{7}$ Interestingly, the slope in the negative domain of past returns is negative but small, indicating that within the domain of losses the average trade size is increasing in the size of the loss from the previous week. While we do not document an overly strong effect, increased risk taking in response to larger losses is congruous with prospect theory preferences. Specifically, it is consistent with the convexity of the value function in the domain of losses, as this suggests that investors become increasingly risk seeking within the domain of losses. Coval and Shumway (2005) document consistent evidence among professional traders on the Chicago Board of Trade (CBOT), finding that within the domain of losses, the smaller the morning loss the smaller the afternoon increase in risk taking. That is, within the domain of losses, CBOT traders become increasingly risk seeking as losses become larger. Other possible explanations for the negative slope on the negative domain are mechanical stop loss orders or that traders get scared and start manually winding down their positions.
} 
addition to the main variables, we also control for week fixed effects (with respect to the trader's first week of trading) and for calendar week fixed effects and trader fixed effects. Standard errors are clustered two-ways in all regressions, by week and trader.

Consistent with traders exhibiting self-attribution bias, the results indicate that the change in average trade size, the change in trade size variability, and the change in the number of trades exhibit a substantially higher sensitivity to returns in the positive domain of returns than in the negative domain of gains. ${ }^{8}$ In the negative domain, the slope is -0.31 (i.e., average trade size increases as losses increase). In the positive domain, the slope is $0.53(0.84-0.31)$, reflecting a difference of 0.84 between the positive and negative domains (Column (1)). The results remain robust when we use the alternative measure for the change in the average trade size based on medians (Column (2)). Similarly, the slope in the positive domain for the change in trade size variability $(0.72-0.17=0.55)$ is substantially greater than the slope in the negative domain $(-$ 0.17), reflecting a difference in slopes of 0.72 (Column (3)).

The change in the number of trades exhibits a different pattern. Specifically, the slopes on the positive domain $(6.76-3.38=3.38)$ is virtually identical to the slope in the negative domain (-3.38), although in a different direction. It appears that traders who experience large gains or losses increase the number of trades substantially, relative to traders who experience more modest gains or losses. We test the robustness of this result by eliminating trader-weeks that have small numbers of trades (e.g., 5 to 10 trades per week): Both slopes become more moderate, but the general pattern remains.

\footnotetext{
${ }^{8}$ We find similar results when examining the growth in the total weekly volume by traders.
} 


\subsection{Discontinuity around Zero Past Returns}

Next, we examine the discontinuity around zero. Panel B of Table 3 employs a regression discontinuity design (RDD) to test for a jump in risk taking and perceived skill at zero. We fit separate third-degree polynomials to the positive and negative domains of past returns and test for a discontinuity at zero by including an indicator variable to capture positive past returns. The regressions display the coefficient on the indicator variable that tests for the existence of a jump. ${ }^{9}$ We face a trade-off in choosing the appropriate degree of polynomial to use. A low-degree polynomial may not be flexible enough to capture the functional form. In contrast, a high-degree polynomial may be attenuated by extreme observations and therefore may not measure the discontinuity around zero well. See Ben-David and Hirshleifer (2012) for a discussion of this technique. In Internet Appendix Table A5, we provide additional analyses that measure the discontinuity with fourth- and fifth-degree polynomials. The results from these tests are consistent with those using the third-degree polynomial.

The coefficients imply that traders increase their average trade size by 0.12 (Column (1)) and their trade size variability by 0.17 (Column (3)) in weeks that follow very small positive returns, relative to weeks with very small negative returns. The results for average trade size are insensitive to whether we use the change in the average trade size or the change in the median trade size (Column (1) versus Column (2)). These effects are very large, given that a one standard deviation change in average trade size and trade size variability is 0.926 and 0.997 , respectively. Thus, the economic effect is $13 \%$ and $17 \%$ of a standard deviation of the weekly changes in average trade size and trade size variability. The jump for the change in the number of trades is

\footnotetext{
${ }^{9}$ Ben-David and Hirshleifer (2012) used a similar methodology to identify jumps around the origin of past returns.
} 
substantial (Column (4)): around zero returns, traders ramp up the number of trades by $55 \% .^{10}$ These results again support the hypothesis that traders suffer from self-attribution bias: Small gains lead to large increases in risk taking and perceived skill, but the same is not true for small losses.

\subsection{Detecting the Discontinuity through Matching}

Another empirical technique to identify the effect of the changes in the trading patterns with respect to past performance is matching. To control for potential differences in types of traders, each week we rank traders into deciles based on week $(t-1)$ trade size and number of trades. We then match traders in week $(t)$ based on week $(t-1)$ decile rankings of trade size and number of traders. Traders are matched to groups based on their week of trading (i.e., how experienced they are, measured as weeks since the first trade in our sample). Then we examine how the behavior of these traders differs based on their realized returns in week $(t-1)$.

We then compare individuals who have just barely lost money to those who have just barely made money. Their returns will place them just on either side of the 0 discontinuity regardless of the denominator used in calculating returns. Our matching procedure matches traders with barely positive profits (defined as $0<\operatorname{ret}(t-1)<0.02 \%$ ) with those with barely negative profits (defined as $-0.02 \%<$ ret $(t-1)<0)$. We match based on week of trading and require traders to be in the same decile of the number of trades in week $(t-1)$ and in the same decile of average trade size in week $(t-1)$.

\footnotetext{
${ }^{10}$ We find similar results when examining the growth in the total weekly volume by traders.
} 
Next, we examine how these traders behave in the following week. Specifically, we look at the week $(t)$ difference in growth in volume, change in trade size variability, and growth in number of trades for traders just to the right relative to just to the left of zero.

The results are presented in Table 3, Panel C. The results show that the matching procedure yields similar estimates for the size of the discontinuity for the change in the average trade size as in the tests in Table 3, Panel B. The result for the change in trade size variability (Column (2)) has similar magnitude (0.13 relative to 0.17 in Panel B); however, it is statistically insignificant, potentially due to loss of power. The result for the change in the number of trades (Column (3)) is statistically significant; however, its magnitude is lower than the one reported in Panel B (0.13 relative to 0.55$)$.

Overall, the results from the matching exercise provide additional evidence that the trading behaviors show a material jump around zero past returns.

\subsection{Graphical Representation}

We plot the relation between our variables of interest and past returns in Figure 2. To produce each panel, we split the trader-week sample into bins of $0.02 \%$ by their value-weighted average returns per trade in week $t-1$ in the region around the origin. We limit the range of the sample to $+/-0.15 \%$ (capturing about $86 \%$ of sample observations). For each group, we calculate the change in average trade size and plot the error bounds for $+/-$ two standard errors around the mean. We overlay on the chart the third-degree polynomial that is produced in Panel B of Table 3 (estimated on the entire sample). Figure 2a demonstrates that the slopes of the change in the average trade size in the positive and negative domains are different, and it also shows a clear 
discontinuity around zero past returns. In Figure 2b, we use the same methodology to chart the change in trade size variability with respect to previous week performance. The figure shows that trade size variability is practically flat in the negative domain of past performance but is increasing in the positive domain. Furthermore, we see a clear discontinuity around zero past returns. Figure 2c shows the relationship for the change in the number of trades. The figure shows that the change in the number of trades has a V-shape, with a discontinuity at zero. Traders increase their trading frequency as returns become more positive in the positive domain. In contrast, they increase their trading activity as past returns are more negative in the negative domain. The strong slope on the negative domain can be explained by traders increasing risk when faced with large losses (Coval and Shumway 2005).

\section{$4.5 \quad$ Robustness}

In this section, we address several concerns regarding the empirical specifications. One possible concern is that the dependent variables are statistics based on individual trades within the week. When few trades are made in a week, then the calculated statistics are measured with noise. The usual econometric treatment for this heteroskedasticity problem is to use weighted least squares (WLS) regressions in which the weight of each observation is the square root of the inverse of its precision. We implement this approach in Internet Appendix Table A6, where we replicate the regressions from Table 3 using WLS. In the regressions for the change in average trade size and change in trade size variability, the weight of each observation is the square root of the average number of trades in weeks $t$ and $t-1$. For the return regressions, the weight of each observation is the square root of the number of trades in week $t$. The results in Internet Appendix Table A6 are almost identical to those in Table 3. 
One concern is that the behavior that we observe is driven by margin calls. In particular, the losses we consider in this study are relatively small on average. Figure 2a provides some comfort regarding this concern. In this figure, we plot the average trade size as a function of previous-week performance. The figure shows a large discontinuity around zero, where the bins of average trade return that we consider are at the size of $0.02 \%$. Of course, some traders have many trades, but even with a hundred trades a week, the average loss that triggers a decline in the average trade size is not likely to be due to a margin call. Furthermore, the negative slope in the domain of losses suggests that traders with losses actually increase their average trade size in the following week, which is inconsistent with a margin call explanation in which traders reduce their positions.

Another concern is that our discontinuity test is misspecified by using zero returns as the focal point. To mitigate this concern, we employ falsification tests to examine the robustness of our results in Table 3, Panel B. The falsification test is presented in Internet Appendix Table A7. We test whether the effects we have documented around zero past returns are present at other random non-zero values. If traders do attribute successes to their own skill and failures to bad luck, then we would not expect to see effects as large around other randomly chosen values. ${ }^{11}$

The falsification tests examine increments of $+/-0.5$ standard deviations of the past week return out to $+/-2$ standard deviations from the origin. The results support the hypothesis that the change in slope and discontinuity is specific to the origin. Panel A of Internet Appendix Table A7 tests for a change in slope for the change in average trade size, and finds that only three of the eight falsification tests are significant at the $5 \%$ level. The same is true for four of the eight tests

\footnotetext{
${ }^{11}$ Note that the predicted theoretical relationship documented in Figure 1 suggests that the slope should be higher to the right of any randomly chosen point relative to the left of that point. However, the effect should be strongest at the origin.
} 
for the change in trade size variability, as displayed in Panel B. The slopes in the positive and negative domains in the regressions of the change in the number of trades (Panel C) are so extreme that all eight tests show a positive and significant difference between the positive and negative domains. However, the difference in the slopes is the largest when the domains are split at the origin.

The results in Panels D to F show that discontinuity is likely to occur only around the origin. Only two of the eight falsification tests exhibit significance at the $5 \%$ level in the predicted direction for the change in average trade size. For the change in trade size variability, none of the eight tests is significant at the $5 \%$ level in the predicted direction. For the change in the number of trades, none of the eight tests is significant at the $5 \%$ level in the predicted direction. Thus, the falsification tests support the hypothesis that the change in slope and discontinuity is specific to zero past week returns.

Finally, we address the critique by Gelman and Imbens (2014) on the RDD method, which uses high-order polynomials for estimating discontinuities. They argue that this method is arbitrary in the degree of polynomials used (i.e., different polynomial degrees can lead to different results) and that the standard errors of the discontinuities estimated using this method may be understated. Gelman and Imbens (2014) instead propose using a linear specification and limiting the sample to the close neighborhood of the discontinuity. We use this approach in Internet Appendix Table A8. We limit the sample to $+/-0.5$ standard deviations $(+/-0.07 \%)$ around the origin and use a simple piece-wise linear specification that estimates the discontinuity.

The regressions in Internet Appendix Table A8 confirm the prior results from Table 3, Panels A and B. The point estimates in this table are generally within $20 \%-30 \%$ of the point estimates in the tables in the main body of the study. 


\subsection{Risk Taking and Perceived Skill: Effects of Past Performance along Traders' Lives}

According to Gervais and Odean (2001), experiences early in a trader's life have a disproportionately large effect on trader overconfidence. Table 4 tests this hypothesis by examining whether the effects that we document in Table 3 are strongest early in a trader's life. To do so, we restrict the sample to traders who survive at least 15 weeks in our sample. This conditioning allows us to avoid a survival bias and ensures that the composition of the sample is constant vis-à-vis weeks of traders' experience. Then, we limit the sample to only trader-week observations taking place in the first five weeks of the trader's life. We repeat this procedure with limitations of 10 weeks and 15 weeks. We repeat the analysis from Table 3 (slopes and discontinuities) for these samples limited by traders’ trading experience.

Consistent with Gervais and Odean (2001), the results clearly suggest that the effect of past returns on risk taking and perceived skill is strongest early in a trader's life. Table 4, Panel A shows that the growth in average trade size, the growth in trade size variability, and the growth in the number of trades, exhibit the strongest response to past returns in the early weeks of trading. As the trader becomes more experienced, the average response becomes smaller: the coefficient decreases in size moving from Column (1) to (4), from Column (5) to (8), and from (9) to (12). We find a similar pattern in Panel B. The magnitude of the discontinuity decreases as traders become more experienced. 


\section{Current Performance and Past Performance}

Lastly, we examine whether traders' performance shares the same patterns exhibited by growth in average trade size, change in trade size variability, and the change in the number of trades, with respect to past returns. As noted before, this is a crucial test because it validates the identification of the effect of overconfidence. If the relation between current and past returns is similar to the relation between past returns and the change in average trade size, trade size variability, or the number of trades, then traders could have potentially interpreted the signals from past performance correctly, and we cannot conclude that they self-attribute positive signals and discard negative ones.

In Tables 5 and 6, we follow an empirical specification similar to that of Tables 2 and 3. The only difference is that the dependent variable is the trader's performance in week $t$. The explanatory variables are the same as before. Table 5 shows that in contrast to the change in trade size, the change in trade size variability, and the growth in number of trades, trader returns show no discontinuity at zero with respect to past returns. Furthermore, the relation between past and future returns does not exhibit an increased slope in the domain of gains relative to the domain of losses.

Table 5, Panel A, is also informative about the overall performance of traders. Specifically, Column (1), which does not include trader fixed effects, shows that there is a positive correlation between current returns and past returns. However, once trader fixed effects are included (Column (2)), the correlation disappears. This suggests that that cross-sectionally there are traders who perform consistently better than others; however, within trader, there is no correlation between current and past returns. 
In several settings, we perform robustness tests of our main results to ensure that the slope of current performance on past performance does not match the pattern of trader behavior (Table 5, Panel A) and that there is no discontinuity around zero returns (Table 5, Panel B). In Internet Appendix Table A5, we measure the discontinuity in current value-weighted average returns around the origin using fourth- and fifth-degree polynomial specifications. The regressions report a small discontinuity in the direction opposite of what we found in trader behavior (Table 3, Panel B). In Internet Appendix Table A6, we repeat the main tests using WLS regressions and find that after adjusting for heteroskedasticity, the results remain similar to the main results.

Table 6 repeats the same test but limits the sample to the first weeks in each trader's life. We see no discernable patterns in the relation between future and past performance as a function of trader experience. The findings in Tables 5 and 6 confirm that the earlier results documenting changes in risk taking and perceived skill are not driven by the relation between current performance and past performance.

The relation between current returns and past returns is graphed in Figure 3. For all values of past returns, traders—on average-lose money in their current trades. In addition, current returns are lower for traders who experienced extreme returns — either very high or very low—in the previous week, likely because these traders enter into volatile trades that result in extreme returns but with very low expected returns. While there are differences in the average levels between positive and negative past performance, there is no discontinuity around zero. Very small losses and very small gains predict the same current performance. Nevertheless, traders attribute much importance to whether they are in the domain of positive or negative performance, as Table 3, Panel B, shows: Average trade size, trade size variability, and number of trades all increase following small gains, relative to small losses. 
Figure 3 also shows that past returns have some predictability for current returns. In the positive domain, the returns are, on average, somewhat higher than those in the negative domain. However, the slopes are opposite of those we document in regard to traders' behavior. In the positive domain, higher past returns are associated with worse current returns. In contrast, the results from the regressions of the change in average trade size, the change in trade size variability, and the change in the number of trades show the opposite: Better past performance induces traders to increase the average trade size, trade size variability, and number of trades. We observe similar divergence in the negative domain: Worse past performance in the negative domain predicts worse current performance. Conversely, within the negative domain, trading behavior appears to be more aggressive (e.g., average trade size increases) following worse negative performance.

Overall, Figure 3 shows that the relation between current and past performance does not explain the strong patterns we observe in trading behavior with respect to past performance. In particular, we note in line with the results in the regressions in Table 5, Panel B, that there is no discontinuity around the origin. In fact, the relation between current returns and past returns around the origin is flat, meaning that small gains or losses have no predictive power over future returns at all. We observe similar results in Internet Appendix Table A8, which offers a modified RDD methodology following Gelman and Imbens (2014).

\section{Conclusion}

Feedback in the form of past performance is important in forming one’s beliefs about skill. However, in certain situations, it may lead irrational individuals to develop overconfidence in their own skill. Specifically, when individuals attribute successes to their own skill and failures to luck, they become overconfident (Daniel, Hirshleifer, and Subrahmanyam 1998, and Gervais and Odean 
2001). Ultimately, overconfidence leads to excess risk taking as the individual discounts the true volatility of the outcome of the action taken.

Our study presents evidence for this mechanism using a sample of Forex day traders. We present evidence that following successful trading periods traders increase risk taking (increase traded amounts), and consistent with increased perceived skill (greater trade size variability and higher frequency of trading). We find no material decline in these variables following periods of losses. Our identification comes from contrasting the response of trader behavior in the positive and negative domains of past performance, as well as identifying the presence of a discontinuity around the origin of past performance. Furthermore, by focusing on a specific subset of investorsextremely active Forex traders who arguably possess very little actual skill—we are able to estimate an upper bound on the economic importance of the effect in real markets.

The findings in this paper expand the academic discussion about the quality of feedback. In our study, there is ample feedback, but traders misinterpret it due to self-attribution. One wonders whether the same applies to other professions or domains, e.g., corporate executives, professional forecasters, weather forecasters, or medical doctors. If the usefulness of feedback differs across domains, it remains an open question what the determinants of this distinction are. Finally, one wonders to what extent our findings of retail trader overconfidence shed light on the behavior of professional traders. Professional traders are certainly not immune to overconfidence, and we therefore expect that our results also provide insight into the behavior of this important group of market participants. We leave these important questions for future research. 


\section{References}

Arkes, Hal R., Caryn Christensen, Cheryl Lai, and Catherine Blumer, 1987, Two Methods of Reducing Overconfidence, Organizational Behavior and Human Decision Processes 39(1), 133-144.

Barber, Brad M., and Terrance Odean, 2000, Trading Is Hazardous to Your Wealth: The Common Stock Investment Performance of Individual Investors, Journal of Finance 55(2), 773-806.

Barber, Brad M., and Terrance Odean, 2002, Online Investors: Do the Slow Die First? Review of Financial Studies 15(2), 455-488.

Ben-David, Itzhak, Justin Birru and Andrea Rossi, 2015, Trading Skill: Evidence from Trades of Corporate Insiders in Their Personal Portfolios, The Ohio State University, Working Paper.

Ben-David, Itzhak, and David Hirshleifer, 2012, Are Investors Really Reluctant to Realize their Losses? Trading Responses to Past Returns and the Disposition Effect, Review of Financial Studies 25(8), 2485-2532.

Campbell, John Y., Tarun Ramadorai, and Benjamin Ranish, 2014, Getting Better or Feeling Better? How Equity Investors Respond to Investment Experiences, Harvard University Working Paper.

Chiang, Yao-Min, David Hirshleifer, Yiming Qian, and Ann E. Sherman, 2011, Do Investors Learn from Experience? Evidence from Frequent IPO Investors, Review of Financial Studies 24(5), 1560-1589.

Choi, Darwin, and Dong Lou, 2010, A Test of the Self-Serving Attribution Bias: Evidence from Mutual Funds, Working Paper.

Choi, James, David Laibson, Brigitte C. Madrian, and Andrew Metrick, 2009, Reinforcement Learning and Savings Behavior, Journal of Finance 64(6), 2515-2534.

Coval, Joshua D., and Tyler Shumway, 2005, Do Behavioral Biases Affect Prices? Journal of Finance 60(1), 1-34.

Daniel, Kent, David, Hirshleifer, Avanidhar Subrahmanyam, 1998, Investor Psychology and Security Market Under and Overreactions, Journal of Finance 53(6), 1839-1885.

Døskeland, Trond M., and Hans K. Hvide, 2011, Do Individual Investors Have Asymmetric Information Based on Work Experience? Journal of Finance 66(3), 1011-1041.

Gelman, Andrew, and Guido Imbens, 2014, Why High-Order Polynomials Should Not be Used in Regression Discontinuity Designs Working paper, Columbia University.

Gervais, Simon, and Itay Goldstein, 2007, The Positive Effects of Biased Self-Perceptions in Firms, Review of Finance 11, 453-496.

Gervais, Simon, J. B. Heaton, and Terrance Odean, 2011, Overconfidence, Compensation Contracts, and Capital Budgeting, Journal of Finance 60(1), 1-34.

Gervais, Simon, and Terrance Odean, 2001, Learning to Be Overconfident, Review of Financial Studies 14(1), 1-27. 
Griffin John M., Federico Nardari, and René M. Stulz, 2006, Do Investors Trade More When Stocks Have Performed Well? Evidence from 46 Countries, Review of Financial Studies 20(3), 905-951.

Grinblatt, Mark, and Matti Keloharju, 2009, Sensation Seeking, Overconfidence, and Trading Activity, Journal of Finance 64(2), 549-578.

Kacperczyk, Marcin, Clemens Sialm, and Lu Zheng, 2005, On the Industry Concentration of Actively Managed Equity Mutual Funds, Journal of Finance 60(4), 1983-2011.

Kaustia, Markuu, and Samuli Knupfer, 2008, Do Investors Overweight Personal Experience? Evidence from IPO Subscriptions, Journal of Finance 63(6), 2679-2702.

Langer, Ellen J., and Jane Roth, 1975, Heads I Win, Tails It's Chance: The Illusion of Control as a Function of the Sequence of Outcomes in a Purely Chance Task, Journal of Personality and Social Psychology 32(6), 951-955.

Linnainmaa, Juhani, 2011, Why Do (Some) Households Trade So Much? Review of Financial Studies 24(5), 1630-1666.

Locke, Peter R., and Seven C. Mann, 2005, Professional Trader Discipline and Trade Disposition, Journal of Financial Economics 76, 401-444.

Mahani, Reza, and Dan Bernhardt, 2007, Financial Speculators' Underperformance: Learning, Self-Selection, and Endogenous Liquidity, Journal of Finance 62(3), 1313-1340.

Malmendier, Ulrike, and Stephan Nagel, 2011, Depression Babies: Do Macroeconomic Experiences Affect Risk Taking? Quarterly Journal of Economics 126 (1), 373-416.

Nicolosi, Gina, Liang Peng, Ning Zhu, 2009, Do Individual Investors Learn from Their Trading Experience, Journal of Financial Markets, 317-336.

Oberlechner, Thomas, and Carol Osler, 2012, Survival of Overconfidence in Currency Markets, Journal of Financial and Quantitative Analysis 47(1), 91-113.

Pool, Veronika K., Noah Stoffman, and Scott E. Yonker, 2012, No Place Like Home: Familiarity in Mutual Fund Manager Portfolio Choice, Review of Financial Studies 25(8), 2563-2599.

Seru Amit, Tyler Shumway, and Noah Stoffman, 2010, Learning by Trading, Review of Financial Studies 23(2), 705-739.

Seidenfeld, Teddy, 1985, Calibration, Coherence, and Scoring Rules, Philosophy of Science 52(2), 274-294.

Statman, Meir, Steven Thorley, and Keith Vorkink, 2006, Investor Overconfidence and Trading Volume, Review of Financial Studies 19(4), 1531-1565.

Thaler, Richard H., 2000, From Homo Economicus to Homo Sapiens, Journal of Economic Perspectives 14(1), 133-141. 


\section{Table 1. Summary Statistics}

Table 1 presents summary statistics for the sample. Panel A displays statistics at the trader level; Panel B displays statistics at the trade level; and Panel C displays statistics at the trader-week level.

\section{Panel A: Trader-Level Summary Statistics}

\begin{tabular}{lcccccccc}
\hline & $\mathrm{N}$ & Mean & St Dev & Min & P25 & P50 & P75 & Max \\
\hline \# Days in Sample & 3,103 & 180.67 & 149.38 & 1 & 46 & 155 & 279 & 563 \\
\# Days Active (Days with Trades) & 3,103 & 50.34 & 53.22 & 1 & 11 & 32 & 70 & 254 \\
\% Profitable at End & 3,103 & 16.21 & 36.86 & 0 & 0 & 0 & 0 & 100 \\
Avg Trade Ret/Trade (\%) & 3,103 & -0.035 & 0.089 & -0.570 & -0.039 & -0.016 & -0.004 & 0.164 \\
Avg Abs Trade Size/Trade (\$) & 3,103 & 21293.31 & 40368.51 & 1224.71 & 2224.19 & 5759.83 & 17578.94 & 235645.83 \\
\# Trades & 3,103 & 341.75 & 514.81 & 2 & 42 & 150 & 399 & 2975 \\
\hline
\end{tabular}

Panel B: Trade-Level Summary Statistics

\begin{tabular}{lcccccccc}
\hline & $\mathrm{N}$ & Mean & St Dev & Min & P25 & P50 & P75 & Max \\
\hline \# Minutes Trade Open & $1,118,632$ & 291.63 & 1065.64 & 0 & 4 & 16 & 83 & 7929 \\
Trades Long (\%) & $1,118,632$ & 47.28 & 49.93 & 0 & 0 & 0 & 100 & 100 \\
Average Trade Return (\%) & $1,118,632$ & -0.009 & 0.204 & -1.120 & -0.038 & 0.015 & 0.056 & 0.578 \\
Trades Profitable (\%) & $1,118,632$ & 62.76 & 48.34 & 0 & 0 & 100 & 100 & 100 \\
Trade Size (\$) & $1,118,632$ & -841.16 & 30383.46 & -139805.00 & -4026.59 & -1300.26 & 2872.53 & 137286.00 \\
Abs Trade Size (\$) & $1,118,632$ & 14230.60 & 29162.89 & 1000.00 & 1414.55 & 3203.78 & 13500.77 & 173101.80 \\
\hline
\end{tabular}

Panel C: Trader-Week-Level Summary Statistics

\begin{tabular}{lcccccccc}
\hline & $\mathrm{N}$ & Mean & St Dev & Min & P25 & P50 & P75 & Max \\
\hline \# Trades/Week & 41,480 & 23.10 & 34.45 & 1 & 4 & 10 & 27 & 214 \\
Weeks Profitable (\%) & 41,480 & 44.07 & 49.65 & 0 & 0 & 0 & 100 & 100 \\
Weeks w Running Profit at Close (\%) & 41,480 & 24.07 & 42.75 & 0 & 0 & 0 & 0 & 100 \\
Average Trade Return (t) (\%) & 41,480 & -0.023 & 0.151 & -0.726 & -0.051 & -0.007 & 0.030 & 0.488 \\
Average Trade Return (t-1) (\%) & 42,880 & -0.021 & 0.145 & -0.726 & -0.049 & -0.007 & 0.030 & 0.488 \\
Change in Avg Trade Size & 42,880 & 0.124 & 0.926 & -1.000 & -0.190 & -0.004 & 0.136 & 6.130 \\
Trade Size Variability (t) & 34,785 & 0.249 & 0.265 & 0.000 & 0.006 & 0.017 & 0.392 & 1.096 \\
Trade Size Variability (t-1) & 34,785 & 0.257 & 0.266 & 0.000 & 0.007 & 0.018 & 0.040 & 1.090 \\
Change in Trade Size Variability & 34,785 & 0.241 & 0.997 & -0.999 & -0.511 & -0.020 & 0.808 & 2.000 \\
\hline
\end{tabular}




\section{Table 2. Is Trade Size Variability a Measure of True Skill?}

This table reports results from regressions in which the dependent variable measures the trade size variability or the change in trade size variability for trader $i$ in week $t$ relative to week $t-1$. Avg Trade $\operatorname{Ret}(t)(\%)$ is a continuous variable equal to the return of trader $i$ in week $t$, represented as percentage points. The trade size variability and the change in trade size variability are represented as fractions. All regressions include week fixed effects. All regressions are OLS regressions. Standard errors are clustered at the trader and week level. $t$-statistics are in parentheses. *, **, $* * *$ denote significance at the $10 \%, 5 \%$, and $1 \%$ level, respectively.

\begin{tabular}{lcc}
\hline Dependent variable: & Trade Size Variability (t) & Change in Trade Size Variability (t) \\
\cline { 2 - 3 } & $(1)$ & $(2)$ \\
\hline Avg Trade Ret (t) (\%) & $-0.13^{* * *}$ & $-0.28^{* * *}$ \\
& $(-11.04)$ & $(-6.03)$ \\
Calendar FE & & \\
Week FE & Yes & Yes \\
Trader FE & Yes & Yes \\
& Yes & Yes \\
Obs & & \\
$\mathrm{R}^{2}$ & 34,785 & 34,785 \\
\end{tabular}




\section{Table 3. Trading Behavior and Past Performance}

This table reports results from regressions in which the dependent variable measures the change in average trade size, the change in trade size variability, or the change in the number of trades for trader $i$ in week $t$ relative to week $t-1$. Avg Trade $\operatorname{Ret}(t-1)(\%)$ is a continuous variable equal to the return of trader $i$ in week $t-1$, represented as percentage points. I(Avg Trade $\operatorname{Ret}(t-1)>0)$ is an indicator variable taking a value of 1 when returns in week $t-1$ are positive. The change in average trade size and the change in trade size variability are represented as fractions. The regressions in Panel B include a third-degree polynomial of returns for the positive and for the negative domains, the coefficients of which are not reported. All regressions include week fixed effects. Trader fixed effects are included where noted. All regressions are OLS regressions. Standard errors are clustered at the trader and week level. $t$-statistics are in parentheses. ${ }^{*}, * *, * * *$ denote significance at the $10 \%, 5 \%$, and $1 \%$ level, respectively.

\section{Panel A: The Slopes of the Trading Behavior Variables with Respect to Past Returns,} around Zero Past Returns

\begin{tabular}{|c|c|c|c|c|}
\hline \multirow[t]{2}{*}{ Dependent variable: } & $\begin{array}{c}\text { Change in Avg } \\
\text { Trade Size (t) }\end{array}$ & $\begin{array}{c}\text { Change in Median } \\
\text { Trade Size (t) } \\
\end{array}$ & $\begin{array}{l}\text { Change in Trade } \\
\text { Size Variability (t) }\end{array}$ & $\begin{array}{c}\text { Change in Number } \\
\text { of Trades (t) }\end{array}$ \\
\hline & (1) & $(2)$ & (3) & $(4)$ \\
\hline Avg Trade Ret (t-1) (\%) & $\begin{array}{l}-0.31^{* * *} \\
(-5.18)\end{array}$ & $\begin{array}{l}-1.43^{* * *} \\
(-3.76)\end{array}$ & $\begin{array}{l}-0.17^{*} \\
(-1.81)\end{array}$ & $\begin{array}{l}-3.38^{* * *} \\
(-14.04)\end{array}$ \\
\hline$\times \mathrm{I}($ Avg Trade Ret $(\mathrm{t}-1)>0)$ & $\begin{array}{l}0.84^{* * *} \\
(6.55)\end{array}$ & $\begin{array}{l}2.14 * * * \\
(4.27)\end{array}$ & $\begin{array}{l}0.72 * * * \\
(4.29)\end{array}$ & $\begin{array}{l}6.76^{* * *} \\
(14.51)\end{array}$ \\
\hline I(Avg Trade Ret $(\mathrm{t}-1)>0)$ & $\begin{array}{l}0.13^{* * *} \\
(9.10)\end{array}$ & $\begin{array}{c}0.08^{*} \\
(1.89)\end{array}$ & $\begin{array}{l}0.22 * * * \\
(15.39)\end{array}$ & $\begin{array}{l}0.52 * * * \\
(16.81)\end{array}$ \\
\hline \# Trades (t-1) & & & & $\begin{array}{l}-0.02 * * * \\
(-8.74)\end{array}$ \\
\hline Calendar FE & Yes & Yes & Yes & Yes \\
\hline Week FE & Yes & Yes & Yes & Yes \\
\hline Trader FE & Yes & Yes & Yes & Yes \\
\hline Obs & 42,880 & 42,880 & 34,785 & 42,880 \\
\hline $\mathrm{R}^{2}$ & 0.014 & 0.004 & 0.025 & 0.056 \\
\hline
\end{tabular}


Table 3. Trading Behavior and Past Performance (Cont.)

Panel B: The Discontinuity in the Trading Behavior Variables with Respect to Past Returns, around Zero Past Returns

\begin{tabular}{|c|c|c|c|c|}
\hline Dependent variable: & $\begin{array}{l}\text { Change in Avg } \\
\text { Trade Size }(\mathrm{t})\end{array}$ & $\begin{array}{c}\text { Change in Median } \\
\text { Trade Size (t) }\end{array}$ & $\begin{array}{l}\text { Change in Trade } \\
\text { Size Variability (t) }\end{array}$ & $\begin{array}{c}\text { Change in Number } \\
\text { of Trades (t) }\end{array}$ \\
\hline & (1) & (2) & (3) & (4) \\
\hline I(Avg Trade Ret (t-1) > 0) & $\begin{array}{l}0.12^{* * *} \\
(6.48)\end{array}$ & $\begin{array}{c}0.16^{* * *} \\
(2.36)\end{array}$ & $\begin{array}{l}0.17^{* * *} \\
(9.29)\end{array}$ & $\begin{array}{c}0.55^{* * *} \\
(9.05)\end{array}$ \\
\hline \# Trades (t-1) & & & & $\begin{array}{l}-0.02^{* * * *} \\
(-8.61)\end{array}$ \\
\hline 3rd degree polynomial & Yes & Yes & Yes & Yes \\
\hline × I(Avg Trade Ret $(\mathrm{t}-1)>0)$ & Yes & Yes & Yes & Yes \\
\hline Calendar FE & Yes & Yes & Yes & Yes \\
\hline Week FE & Yes & Yes & Yes & Yes \\
\hline Trader FE & Yes & Yes & Yes & Yes \\
\hline Obs & 42,880 & 42,880 & 34,785 & 42,880 \\
\hline $\mathrm{R}^{2}$ & 0.015 & 0.005 & 0.025 & 0.056 \\
\hline
\end{tabular}


Table 3. Trading Behavior and Past Performance (Cont.)

Panel C: A Matching Approach to the Discontinuity in the Trading Behavior Variables with Respect to Past Returns, around Zero Past Returns

\begin{tabular}{|c|c|c|c|}
\hline Dependent variable: & $\begin{array}{l}\text { Change in Avg } \\
\text { Trade Size (t) }\end{array}$ & $\begin{array}{l}\text { Change in Trade } \\
\text { Size Variability (t) }\end{array}$ & $\begin{array}{c}\text { Change in Number } \\
\text { of Trades (t) }\end{array}$ \\
\hline & $(1)$ & $(2)$ & (3) \\
\hline I(Avg Trade Ret $(\mathrm{t}-1)>0)$ & $\begin{array}{c}0.12^{* * *} \\
(9.32)\end{array}$ & $\begin{array}{c}0.13 \\
(0.12)\end{array}$ & $\begin{array}{c}0.13^{* * *} \\
(4.35)\end{array}$ \\
\hline Matched cell FE & Yes & Yes & Yes \\
\hline Calendar FE & Yes & Yes & Yes \\
\hline Week FE & Yes & Yes & Yes \\
\hline Obs & 6,696 & 5,727 & 6,696 \\
\hline $\mathrm{R}^{2}$ & 0.011 & 0.004 & 0.023 \\
\hline
\end{tabular}




\section{Table 4. Trading Behavior with Respect to Past Returns, by Trading Experience}

This table reports results from regressions in which the dependent variable measures the change in average trade size, the change in trade size variability, or the change in the number of trades for trader $i$ in week $t$ relative to week $t-1$. Avg Trade $\operatorname{Ret}(t-1)(\%)$ is a continuous variable equal to the return of trader $i$ in week $t-1$, represented as percentage points. I(Avg Trade $\operatorname{Ret}(t-1)>0)$ is an indicator variable taking a value of 1 when returns in week $t-1$ are positive. The change in average trade size and the change in trade size variability are represented as fractions. The sample is limited to the first five weeks of trading for each trader (Columns (1), (5), (9)), the first 10 weeks of trading for each trader (Columns (2), (6), (10)), the first 15 weeks of trading for each trader (Columns (3), (7), (11)), or all traderweeks (Columns (4), (8), (12)). To enter the sample, a trader needs to survive at least 15 weeks. The regressions in Panel B include a third-degree polynomial of returns for the positive and for the negative domains, the coefficients of which are not reported. All regressions include week fixed effects. Trader fixed effects are included where noted. All regressions are OLS regressions. Standard errors are clustered at the trader and week level. $t$-statistics are in parentheses. ${ }^{*}, * *, * *$ denote significance at the $10 \%, 5 \%$, and $1 \%$ level, respectively.

\section{Panel A: The Slopes of the Trading Behavior Variables with Respect to Past Returns, around Zero Past Returns, by Trading Experience}

\begin{tabular}{|c|c|c|c|c|c|c|c|c|c|}
\hline \multirow{2}{*}{\multicolumn{2}{|c|}{$\begin{array}{l}\text { Dependent variable: } \\
\text { Weeks: }\end{array}$}} & \multicolumn{4}{|c|}{ Change in Avg Trade Size (t) } & \multicolumn{4}{|c|}{ Change in Trade Size Variability (t) } \\
\hline & & \multirow{2}{*}{$\frac{\leq 5}{(1)}$} & \multirow{2}{*}{$\begin{array}{c}\leq 10 \\
(2)\end{array}$} & \multirow{2}{*}{$\frac{\leq 15}{(3)}$} & \multirow{2}{*}{$\begin{array}{l}\text { All } \\
(4) \\
\end{array}$} & \multirow{2}{*}{$\frac{\leq 5}{(5)}$} & \multirow{2}{*}{$\frac{\leq 10}{(6)}$} & \multirow{2}{*}{$\begin{array}{c}\leq 15 \\
(7)\end{array}$} & \multirow{2}{*}{$\begin{array}{l}\text { All } \\
(8) \\
\end{array}$} \\
\hline & & & & & & & & & \\
\hline \multicolumn{2}{|c|}{ Avg Trade Ret (t-1) (\%) } & $\begin{array}{c}-0.92 * * * \\
(-4.90)\end{array}$ & $\begin{array}{r}-0.83^{* * *} \\
(-9.43)\end{array}$ & $\begin{array}{c}-0.71^{* * *} \\
(-9.31)\end{array}$ & $\begin{array}{c}-0.42^{* * *} \\
(-6.03)\end{array}$ & $\begin{array}{c}-0.34 \\
(-1.05)\end{array}$ & $\begin{array}{c}-0.14 \\
(-0.81)\end{array}$ & $\begin{array}{l}-0.125 \\
(-0.92)\end{array}$ & $\begin{array}{l}-0.108 \\
(-1.10)\end{array}$ \\
\hline \multicolumn{2}{|c|}{$\times \mathrm{I}($ Avg Trade Ret $(\mathrm{t}-1)>0)$} & $\begin{array}{c}1.93^{* * *} \\
(4.10)\end{array}$ & $\begin{array}{c}1.80^{* * *} \\
(6.88)\end{array}$ & $\begin{array}{c}1.56^{* * *} \\
(8.71)\end{array}$ & $\begin{array}{c}0.95^{* * *} \\
(6.53)\end{array}$ & $\begin{array}{c}1.54^{* * *} \\
(3.04)\end{array}$ & $\begin{array}{c}1.09 * * * \\
(2.63)\end{array}$ & $\begin{array}{c}0.99 * * * \\
(3.62)\end{array}$ & $\begin{array}{c}0.63^{* * * *} \\
(3.90)\end{array}$ \\
\hline \multicolumn{2}{|c|}{ I(Avg Trade Ret $(\mathrm{t}-1)>0)$} & $\begin{array}{c}0.18^{* * *} \\
(3.25)\end{array}$ & $\begin{array}{c}0.15^{* * *} \\
(8.43)\end{array}$ & $\begin{array}{c}0.13^{* * *} \\
(5.90)\end{array}$ & $\begin{array}{c}0.12^{* * *} \\
(8.97)\end{array}$ & $\begin{array}{c}0.26^{* * *} \\
(8.01)\end{array}$ & $\begin{array}{c}0.22^{* * *} \\
(9.20)\end{array}$ & $\begin{array}{c}0.19 * * * \\
(9.08)\end{array}$ & $\begin{array}{c}0.21^{* * *} \\
(12.45)\end{array}$ \\
\hline \multirow{3}{*}{\multicolumn{2}{|c|}{$\begin{array}{l}\text { Calendar FE } \\
\text { Week FE } \\
\text { Trader FE }\end{array}$}} & Yes & Yes & Yes & Yes & Yes & Yes & Yes & Yes \\
\hline & & Yes & Yes & Yes & Yes & Yes & Yes & Yes & Yes \\
\hline & & Yes & Yes & Yes & Yes & Yes & Yes & Yes & Yes \\
\hline \multirow{2}{*}{\multicolumn{2}{|c|}{$\begin{array}{l}\text { Obs } \\
\mathrm{R}^{2}\end{array}$}} & 4,833 & 10,859 & 16,888 & 33,188 & 4,247 & 9,378 & 14,396 & 27,361 \\
\hline & & 0.038 & 0.026 & 0.020 & 0.014 & 0.050 & 0.035 & 0.028 & 0.025 \\
\hline & Dependent v & ariable: & & Chal & nge in Num & er of Trade & $\mathrm{s}(\mathrm{t})$ & & \\
\hline & Weeks: & & & $\leq 5$ & $\leq 10$ & $\leq 15$ & All & & \\
\hline & & & & (9) & $(10)$ & $(11)$ & $(12)$ & & \\
\hline & $\overline{\text { Avg Trade } \mathrm{R}}$ & et $(t-1)(\%$ & & $\begin{array}{c}-5.63 * * * \\
(-5.40)\end{array}$ & $\begin{array}{c}-5.49 * * * \\
(-12.62)\end{array}$ & $\begin{array}{c}-4.83^{* * *} \\
(-10.33)\end{array}$ & $\begin{array}{l}-3.58 * * * \\
(-11.71)\end{array}$ & & \\
\hline & $\times \mathrm{I}($ Avg $\operatorname{Tr}$ & ade Ret $(\mathrm{t}-$ & 1) $>x)$ & $\begin{array}{c}11.36^{* * *} \\
(7.32)\end{array}$ & $\begin{array}{c}10.01^{* * *} \\
(11.91)\end{array}$ & $\begin{array}{l}9.11^{* * *} \\
(12.38)\end{array}$ & $\begin{array}{l}6.96 * * * \\
(13.28)\end{array}$ & & \\
\hline & I(Avg Trade & Ret $(\mathrm{t}-1)>$ & & $\begin{array}{c}0.66^{* * *} \\
(6.99)\end{array}$ & $\begin{array}{c}0.57 * * * \\
(11.48)\end{array}$ & $\begin{array}{l}0.50^{* * *} \\
(10.58)\end{array}$ & $\begin{array}{l}0.49 * * * \\
(15.82)\end{array}$ & & \\
\hline & \# Trades ( $\mathrm{t}-1$ & & & $\begin{array}{c}-0.02 * * * \\
(-4.50)\end{array}$ & $\begin{array}{c}-0.02 * * * \\
(-6.62)\end{array}$ & $\begin{array}{c}-0.02 * * * \\
(-7.54)\end{array}$ & $\begin{array}{c}-0.02^{* * *} \\
(-10.97)\end{array}$ & & \\
\hline & Calendar FE & & & Yes & Yes & Yes & Yes & & \\
\hline & Week FE & & & Yes & Yes & Yes & Yes & & \\
\hline & Trader FE & & & Yes & Yes & Yes & Yes & & \\
\hline & Obs & & & 4,833 & 10,859 & 16,888 & 33,188 & & \\
\hline & $\mathrm{R}^{2}$ & & & 0.210 & 0.149 & 0.134 & 0.115 & & \\
\hline
\end{tabular}


Table 4. Trading Behavior with Respect to Past Returns, by Trading Experience (Cont.)

Panel B: The Discontinuity in the Trading Behavior Variables with Respect to Past

Returns, around Zero Past Returns, by Trading Experience

\begin{tabular}{|c|c|c|c|c|c|c|c|c|}
\hline \multirow{3}{*}{$\begin{array}{l}\text { Dependent variable: } \\
\text { Weeks: }\end{array}$} & \multicolumn{4}{|c|}{ Change in Avg Trade Size (t) } & \multicolumn{4}{|c|}{ Change in Trade Size Variability (t) } \\
\hline & $\leq 5$ & $\leq 10$ & $\leq 15$ & All & $\leq 5$ & $\leq 10$ & $\leq 15$ & All \\
\hline & (1) & $(2)$ & $(3)$ & (4) & (5) & $(6)$ & $(7)$ & $(8)$ \\
\hline I(Avg Trade Ret $(\mathrm{t}-1)>0)$ & $\begin{array}{c}0.27 * * * \\
(4.41)\end{array}$ & $\begin{array}{c}0.19 * * * \\
(4.94)\end{array}$ & $\begin{array}{c}0.14^{* * *} \\
(4.36)\end{array}$ & $\begin{array}{c}0.12 * * * \\
(6.78)\end{array}$ & $\begin{array}{c}0.19 * * * \\
(3.74)\end{array}$ & $\begin{array}{c}0.19 * * * \\
(3.91)\end{array}$ & $\begin{array}{c}0.17^{* * *} \\
(4.91)\end{array}$ & $\begin{array}{l}0.16^{* * *} \\
(7.41)\end{array}$ \\
\hline 3rd degree polynomial & Yes & Yes & Yes & Yes & Yes & Yes & Yes & Yes \\
\hline$\times \mathrm{I}($ Avg Trade Ret $(\mathrm{t}-1)>0)$ & Yes & Yes & Yes & Yes & Yes & Yes & Yes & Yes \\
\hline Calendar FE & Yes & Yes & Yes & Yes & Yes & Yes & Yes & Yes \\
\hline Week FE & Yes & Yes & Yes & Yes & Yes & Yes & Yes & Yes \\
\hline Trader FE & Yes & Yes & Yes & Yes & Yes & Yes & Yes & Yes \\
\hline Obs & 4,833 & 10,859 & 16,888 & 33,188 & 4,247 & 9,378 & 14,396 & 27,631 \\
\hline $\mathrm{R}^{2}$ & 0.041 & 0.028 & 0.021 & 0.015 & 0.051 & 0.036 & 0.0282 & 0.025 \\
\hline
\end{tabular}

\begin{tabular}{|c|c|c|c|c|}
\hline \multirow{3}{*}{$\begin{array}{l}\text { Dependent variable: } \\
\text { Weeks: }\end{array}$} & \multicolumn{4}{|c|}{ Change in Number of Trades (t) } \\
\hline & $\leq 5$ & $\leq 10$ & $\leq 15$ & All \\
\hline & (9) & $(10)$ & $(11)$ & $(12)$ \\
\hline I(Avg Trade Ret (t-1) > x) & $\begin{array}{c}0.75^{* * *} \\
(3.78)\end{array}$ & $\begin{array}{c}0.55^{* * *} \\
(3.87)\end{array}$ & $\begin{array}{l}0.52 * * * \\
(4.90)\end{array}$ & $\begin{array}{c}0.51^{* * * *} \\
(8.11)\end{array}$ \\
\hline \# Trades (t-1) & $\begin{array}{c}-0.02 * * * \\
(-4.52)\end{array}$ & $\begin{array}{c}-0.02 * * * \\
(-6.66)\end{array}$ & $\begin{array}{c}-0.02 * * * \\
(-7.49)\end{array}$ & $\begin{array}{c}-0.02^{* * *} \\
(-10.84)\end{array}$ \\
\hline 3rd degree polynomial & Yes & Yes & Yes & Yes \\
\hline × I(Avg Trade Ret $(\mathrm{t}-1)>\mathrm{x})$ & Yes & Yes & Yes & Yes \\
\hline Calendar FE & Yes & Yes & Yes & Yes \\
\hline Week FE & Yes & Yes & Yes & Yes \\
\hline Trader FE & Yes & Yes & Yes & Yes \\
\hline Obs & 4,833 & 10,859 & 16,888 & 33,188 \\
\hline $\mathrm{R}^{2}$ & 0.212 & 0.150 & 0.135 & 0.116 \\
\hline
\end{tabular}




\section{Table 5. Current Performance and Past Performance}

This table reports results from regressions of returns in week $t$ as predicted by returns in week $t-1$. The dependent variable is the return of trader $i$ in week $t$. Avg Trade $\operatorname{Ret}(t-1)(\%)$ is a continuous variable equal to the return of trader $i$ in week $t-1$, represented as percentage points. I(Avg Trade $\operatorname{Ret}(t-1)>0)$ is an indicator variable taking a value of 1 when returns in week $t-1$ are positive. The regressions in Panel B include a third-degree polynomial of returns for the positive and for the negative domains, the coefficients of which are not reported. All regressions include week fixed effects. Trader fixed effects are included where noted. All regressions are OLS regressions. Standard errors are clustered at the trader and week level. $t$-statistics are in parentheses. *, **, *** denote significance at the $10 \%$, 5\%, and $1 \%$ level, respectively.

Panel A: The Slopes of Current Performance with Respect to Past Performance

\begin{tabular}{lcc}
\hline Dependent variable: & \multicolumn{2}{c}{ Average Trade Return (t) (\%) } \\
\cline { 2 - 3 } & $0.07^{* * *}$ & $(2)$ \\
\hline Avg Trade Ret $(\mathrm{t}-1)(\%)$ & $(6.00)$ & $(-1.23)$ \\
& $-0.13^{* * *}$ & $-0.08^{* * *}$ \\
$\times$ I(Avg Trade Ret $(\mathrm{t}-1)>0)$ & $(-4.94)$ & $(-2.70)$ \\
& & \\
I(Avg Trade Ret $(\mathrm{t}-1)>0)$ & $0.01^{* * *}$ & 0.00 \\
& $(3.18)$ & $(-1.05)$ \\
Calendar FE & & \\
Week FE & Yes & Yes \\
Trader FE & Yes & Yes \\
& No & Yes \\
Obs & & \\
$\mathrm{R}^{2}$ & 41,480 & 41,480 \\
\hline
\end{tabular}

Panel B: Is There a Discontinuity around Zero for Current Performance with Respect to Past Performance?

\begin{tabular}{lcc}
\hline Dependent variable: & \multicolumn{2}{c}{ Average Trade Return $(\mathrm{t})(\%)$} \\
\cline { 2 - 3 } & $(1)$ & $(2)$ \\
\hline $\mathrm{I}($ Avg Trade Ret $(\mathrm{t}-1)>0)$ & -0.0027 & $-0.0055^{*}$ \\
& $(-0.91)$ & $(-1.86)$ \\
& & \\
3rd degree polynomial & Yes & Yes \\
$\quad \times$ I(Avg Trade Ret $(\mathrm{t}-1)>0)$ & Yes & Yes \\
Calendar FE & Yes & Yes \\
Week FE & Yes & Yes \\
Trader FE & No & Yes \\
& & \\
Obs & 41,480 & 41,480 \\
$\mathrm{R}^{2}$ & 0.012 & 0.015 \\
\hline
\end{tabular}




\section{Table 6. Current Performance and Past Performance, by Trading Period}

This table reports results from regressions of the average trade return in week $t$ as predicted by the return in week $t-$ 1. The dependent variable is the return of trader $i$ in week $t$. Avg Trade $\operatorname{Ret}(t-1)(\%)$ is a continuous variable equal to the return of trader $i$ in week $t-1$, represented as percentage points. I(Avg $\operatorname{Trade} \operatorname{Ret}(t-1)>0)$ is an indicator variable taking a value of 1 when returns in week $t-1$ are positive. The change in average trade size and the change in trade size variability are represented as fractions. The regressions in Panel B include a third-degree polynomial of returns for the positive and for the negative domains, the coefficients of which are not reported. All regressions include week fixed effects. Trader fixed effects are included where noted. All regressions are OLS regressions. Standard errors are clustered at the trader and week level. $t$-statistics are in parentheses. *, **, *** denote significance at the $10 \%, 5 \%$, and $1 \%$ level, respectively.

Panel A: The Slopes of Current Performance with Respect to Past Performance, by Trading Period

\begin{tabular}{|c|c|c|c|c|}
\hline \multirow{3}{*}{$\begin{array}{l}\text { Dependent variable: } \\
\text { Week: }\end{array}$} & \multicolumn{4}{|c|}{ Average Trade Return (t) (\%) } \\
\hline & $\leq 5$ & $\leq 10$ & $\leq 15$ & All \\
\hline & (1) & $(2)$ & (3) & (4) \\
\hline \multirow[t]{2}{*}{ Avg Trade Ret (t-1) (\%) } & $-0.24^{* * *}$ & $-0.11^{* * *}$ & -0.03 & 0.02 \\
\hline & $(-4.16)$ & $(-6.04)$ & $(-1.52)$ & (1.11) \\
\hline \multirow[t]{2}{*}{$\times \mathrm{I}($ Avg Trade Ret $(\mathrm{t}-1)>0)$} & -0.06 & -0.08 & $-0.09 * *$ & $-0.10^{* * *}$ \\
\hline & $(-0.63)$ & $(-1.45)$ & $(-2.22)$ & $(-3.03)$ \\
\hline \multirow[t]{2}{*}{ I(Avg Trade Ret (t-1) > 0) } & 0.00 & 0.00 & 0.00 & 0.00 \\
\hline & $(0.03)$ & (1.15) & -0.95 & -1.32 \\
\hline Calendar FE & Yes & Yes & Yes & Yes \\
\hline Week FE & Yes & Yes & Yes & Yes \\
\hline Trader FE & Yes & Yes & Yes & Yes \\
\hline Obs & 4,833 & 10,859 & 16,888 & 32,831 \\
\hline $\mathrm{R}^{2}$ & 0.084 & 0.034 & 0.02 & 0.0138 \\
\hline
\end{tabular}


Table 6. Current Performance and Past Performance, by Trading Period (Cont.)

Panel B: Is There a Discontinuity around Zero for Current Performance with Respect to Past Performance, by Trading Period?

\begin{tabular}{|c|c|c|c|c|}
\hline \multirow{3}{*}{$\begin{array}{l}\text { Dependent variable: } \\
\text { Week: }\end{array}$} & \multicolumn{4}{|c|}{ Average Trade Return (t) (\%) } \\
\hline & $\leq 5$ & $\leq 10$ & $\leq 15$ & All \\
\hline & $(1)$ & $(2)$ & $(3)$ & $(4)$ \\
\hline \multirow[t]{2}{*}{ I(Avg Trade Ret $(\mathrm{t}-1)>0)$} & -0.0080 & -0.0002 & -0.0070 & $-0.0060^{*}$ \\
\hline & $(-0.97)$ & $(-0.03)$ & $(-1.10)$ & $(-1.86)$ \\
\hline \multirow{2}{*}{$\begin{array}{l}\text { 3rd degree polynomial } \\
\quad \times \text { I }(\text { Avg Trade Ret }(\mathrm{t}-1)>0)\end{array}$} & Yes & Yes & Yes & Yes \\
\hline & Yes & Yes & Yes & Yes \\
\hline Calendar FE & Yes & Yes & Yes & Yes \\
\hline Week FE & Yes & Yes & Yes & Yes \\
\hline Trader FE & Yes & Yes & Yes & Yes \\
\hline Obs & 4,833 & 10,859 & 16,888 & 32,831 \\
\hline $\mathrm{R}^{2}$ & 0.092 & 0.036 & 0.022 & 0.0147 \\
\hline
\end{tabular}


Figure 1. Hypothesis: Risk Taking and Perceived Skill Have Differential Slopes and Discontinuity around Zero Past Performance

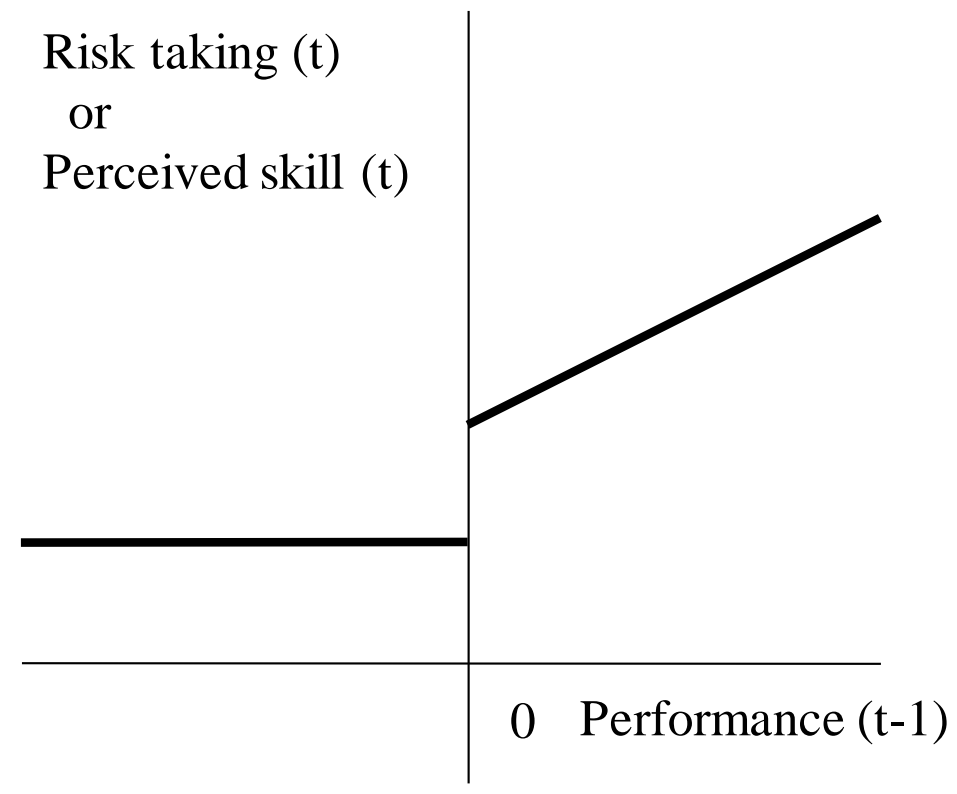

The figure illustrates the hypotheses that individuals respond to past performance in an asymmetric manner (different slope) with respect to gains and losses and that they may exhibit a discontinuity around the origin of past performance. 


\section{Figure 2. Change in Trading Patterns and Past Performance}

The figures show the change in trading patterns as a function of the lagged average trade return. The change in average trade size is computed as the change in the average amount invested in each trade as a fraction of the initial balance at week $t-1$. Observations (trader-week) are sorted into bins of $0.02 \%$. In each bin, the diamond marker indicates the average, and the small x's represent two standard errors from the mean. The solid line represents a third-degree polynomial fit (separate fit for positive and negative domains).

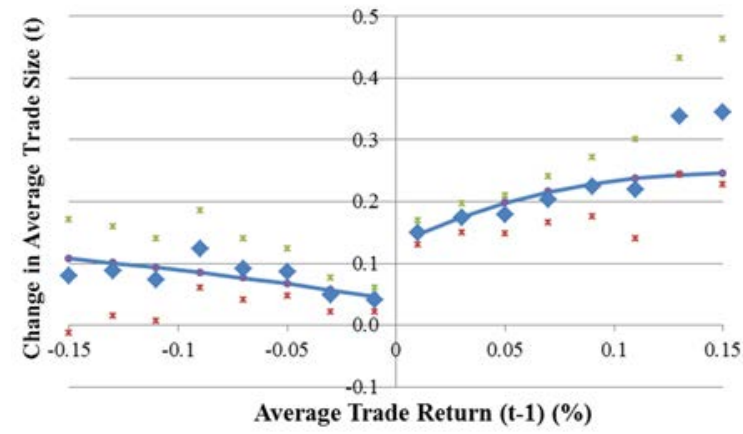

Figure 2a. Change in Average Trade Size and Past Performance

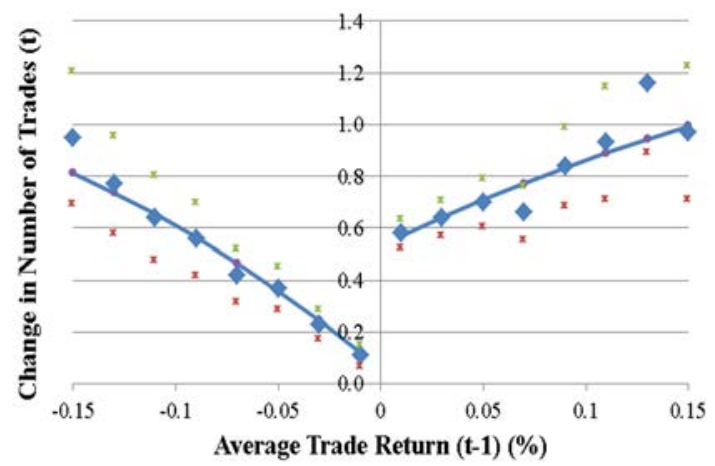

Figure 2c. Change in the Number of Trades and Past Performance

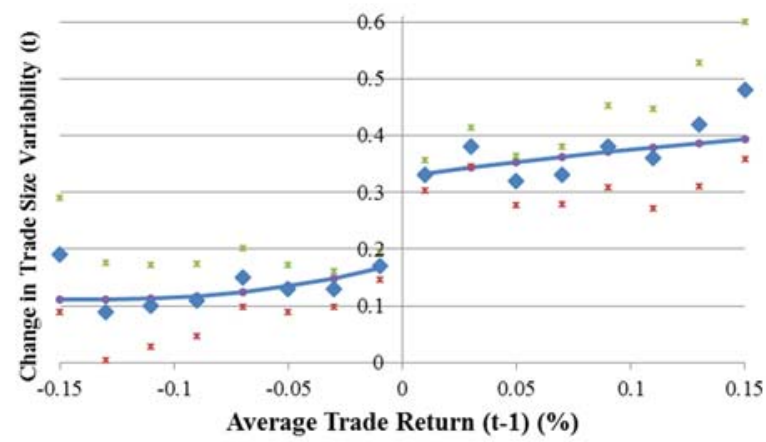

Figure 2b. Change in Trade Size Variability and Past Performance 
Figure 3. Current Performance and Past Performance

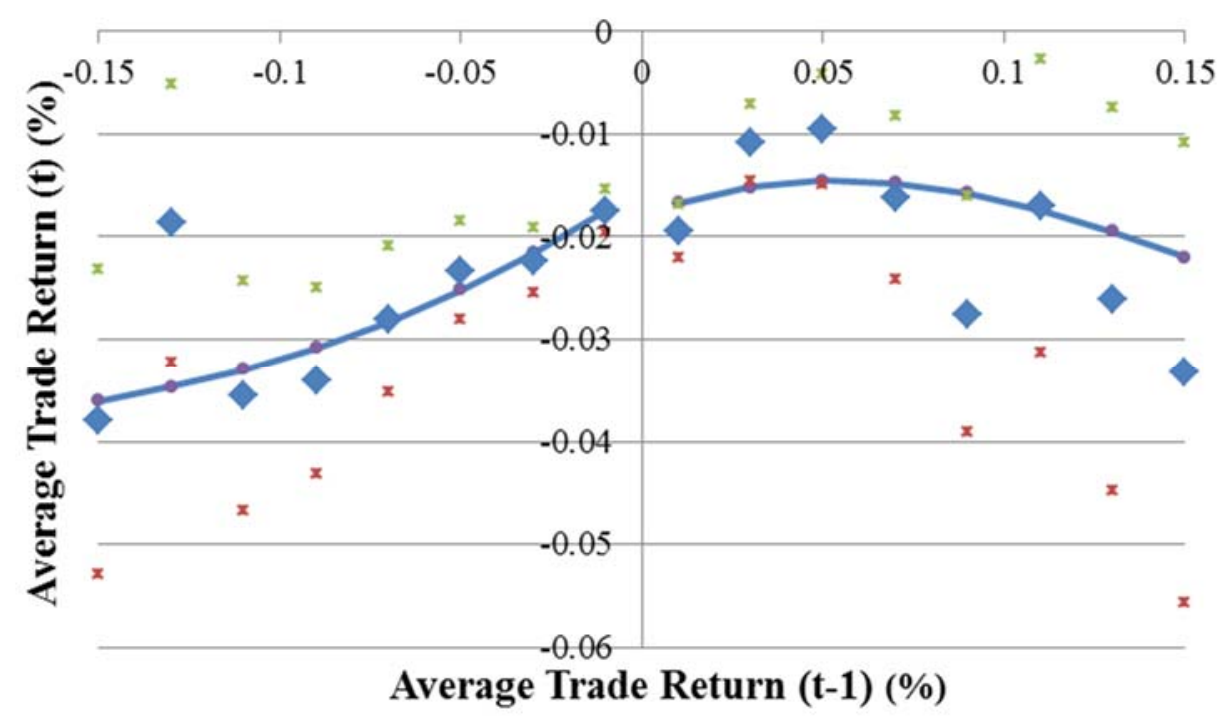

The figure shows the weekly average trade return of traders as a function of the lagged average trade return. Observations (trader-week) are sorted into bins of $0.02 \%$. In each bin, the diamond marker indicates the average, and the small x's represent two standard errors from the mean. The solid line represents a third-degree polynomial fit (separate fit for positive and negative domains). 


\title{
Uninformative Feedback and Risk Taking: Evidence from Retail Forex Trading
}

\author{
Itzhak Ben-David \\ Fisher College of Business, The Ohio State University, and NBER \\ Justin Birru \\ Fisher College of Business, The Ohio State University \\ Viktor Prokopenya \\ $\exp ($ Capital)
}

March 2016

INTERNET APPENDIX 


\section{Internet Appendix Table A1. Main Tests with Three-Day Frequency}

This table reports results from regressions in which the dependent variable measures the change in average trade size or change in trade size variability for trader $i$ in the two-week period $t$ relative to the three-day period $t-1$. Avg Trade $\operatorname{Ret}(t-1)(\%)$ is a continuous variable equal to the return of trader $i$ in the two-week period $t-1$, represented as percentage points. I(Avg Trade $\operatorname{Ret}(t-1)>0)$ is an indicator variable taking a value of 1 when past value-weighted average returns are positive. The change in average trade size, the change in trade size variability, and the change in the number of trades, are represented as fractions. The regressions in Panel B include a third-degree polynomial of returns for the positive and for the negative domains, the coefficients of which are not reported. All regressions include week fixed effects. Trader fixed effects are included where noted. All regressions are OLS regressions. Standard errors are clustered at the trader and week level. $t$-statistics are in parentheses. *, **, *** denote significance at the $10 \%, 5 \%$, and $1 \%$ level, respectively.

\section{Panel A: The Slopes of the Trading Patterns with Respect to Past Returns, around Zero} Past Returns (Three-Day Frequency)

\begin{tabular}{|c|c|c|c|c|c|c|}
\hline \multirow[t]{2}{*}{ Dependent variable: } & \multicolumn{2}{|c|}{$\begin{array}{l}\text { Change in Avg } \\
\text { Trade Size (t) }\end{array}$} & \multicolumn{2}{|c|}{$\begin{array}{l}\text { Change in Trade } \\
\text { Size Variability (t) } \\
\end{array}$} & \multicolumn{2}{|c|}{$\begin{array}{c}\text { Change in Number } \\
\text { of Trades (t) }\end{array}$} \\
\hline & $(1)$ & $(2)$ & (3) & (4) & (5) & $(6)$ \\
\hline Avg Trade Ret (t-1) (\%) & $\begin{array}{c}-0.22 * * * \\
(-5.06)\end{array}$ & $\begin{array}{c}-0.32 * * * \\
(-6.78)\end{array}$ & $\begin{array}{l}-0.10^{*} \\
(-1.63)\end{array}$ & $\begin{array}{c}-0.29 * * * \\
(-4.47)\end{array}$ & $\begin{array}{l}-1.85^{* * *} \\
(-13.91)\end{array}$ & $\begin{array}{l}-3.24^{* * *} \\
(-21.08)\end{array}$ \\
\hline$\times \mathrm{I}($ Avg Trade Ret $(\mathrm{t}-1)>0)$ & $\begin{array}{c}0.51^{* * *} \\
(7.98)\end{array}$ & $\begin{array}{c}0.70^{* * *} \\
(9.64)\end{array}$ & $\begin{array}{c}0.35^{* * *} \\
(3.28)\end{array}$ & $\begin{array}{c}0.71 * * * \\
(6.32)\end{array}$ & $\begin{array}{l}3.64 * * * \\
(12.84)\end{array}$ & $\begin{array}{l}6.47^{* * *} \\
(19.69)\end{array}$ \\
\hline I(Avg Trade Ret $(\mathrm{t}-1)>0)$ & $\begin{array}{c}0.07 * * * \\
(6.65)\end{array}$ & $\begin{array}{c}0.09 * * * \\
(7.80)\end{array}$ & $\begin{array}{l}0.16^{* * *} \\
(14.17)\end{array}$ & $\begin{array}{l}0.20 * * * \\
(16.17)\end{array}$ & $\begin{array}{l}0.46^{* * *} \\
(18.41)\end{array}$ & $\begin{array}{l}0.64^{* * *} \\
(23.50)\end{array}$ \\
\hline Calendar FE & Yes & Yes & Yes & Yes & Yes & Yes \\
\hline Week FE & Yes & Yes & Yes & Yes & Yes & Yes \\
\hline Trader FE & No & Yes & No & Yes & No & Yes \\
\hline Obs & 78,161 & 78,161 & 56,407 & 56,407 & 78,161 & 78,161 \\
\hline $\mathrm{R}^{2}$ & 0.011 & 0.013 & 0.050 & 0.052 & 0.080 & 0.097 \\
\hline
\end{tabular}

Panel B: The Discontinuity in the Trading Patterns with Respect to Past Returns, around Zero Past Returns (Three-Day Frequency)

\begin{tabular}{|c|c|c|c|c|c|c|}
\hline \multirow[t]{2}{*}{ Dependent variable: } & \multicolumn{2}{|c|}{$\begin{array}{c}\text { Change in Avg } \\
\text { Trade Size (t) }\end{array}$} & \multicolumn{2}{|c|}{$\begin{array}{l}\text { Change in Trade } \\
\text { Size Variability (t) }\end{array}$} & \multicolumn{2}{|c|}{$\begin{array}{c}\text { Change in Number } \\
\text { of Trades (t) }\end{array}$} \\
\hline & $(1)$ & $(2)$ & (3) & (4) & (5) & $(6)$ \\
\hline I(Avg Trade Ret $(\mathrm{t}-1)>0)$ & $\begin{array}{c}0.09 * * * \\
(5.71)\end{array}$ & $\begin{array}{c}0.10^{* * *} \\
(6.94)\end{array}$ & $\begin{array}{l}0.16^{* * *} \\
(11.40)\end{array}$ & $\begin{array}{l}0.18 * * * \\
(12.35)\end{array}$ & $\begin{array}{l}0.67 * * * \\
(20.25)\end{array}$ & $\begin{array}{l}0.09 * * * \\
(22.89)\end{array}$ \\
\hline 3rd degree polynomial & Yes & Yes & Yes & Yes & Yes & Yes \\
\hline$\times$ I(Avg Trade Ret $(\mathrm{t}-1)>0)$ & Yes & Yes & Yes & Yes & Yes & Yes \\
\hline Calendar FE & Yes & Yes & Yes & Yes & Yes & Yes \\
\hline Week FE & Yes & Yes & Yes & Yes & Yes & Yes \\
\hline Trader FE & No & Yes & No & Yes & No & Yes \\
\hline Obs & 78,161 & 78,161 & 56,407 & 56,407 & 78,161 & 78,161 \\
\hline $\mathrm{R}^{2}$ & 0.011 & 0.013 & 0.050 & 0.052 & 0.083 & 0.103 \\
\hline
\end{tabular}




\section{Internet Appendix Table A2. Main Tests with Two-Week Frequency}

This table reports results from regressions in which the dependent variable measures change in average trade size or change in trade size variability for trader $i$ in the two-week period $t$ relative to the two-week period $t-1$. Avg Trade $\operatorname{Ret}(t-1)(\%)$ is a continuous variable equal to the return of trader $i$ in the two-week period $t-1$, represented as percentage points. I(Avg Trade $\operatorname{Ret}(t-1)>0)$ is an indicator variable taking a value of 1 when past value-weighted average returns are positive. The change in average trade size, the change in trade size variability, and the change in the number of trades, are represented as fractions. The regressions in Panel B include a third-degree polynomial of returns for the positive and for the negative domains, the coefficients of which are not reported. All regressions include week fixed effects. Trader fixed effects are included where noted. All regressions are OLS regressions. Standard errors are clustered at the trader and week level. $t$-statistics are in parentheses. *, **, *** denote significance at the $10 \%, 5 \%$, and $1 \%$ level, respectively.

Panel A: The Slopes of the Trading Patterns with Respect to Past Returns, around Zero Past Returns (Two-Week Frequency)

\begin{tabular}{|c|c|c|c|c|c|c|}
\hline \multirow[t]{2}{*}{ Dependent variable: } & \multicolumn{2}{|c|}{$\begin{array}{c}\text { Change in Avg } \\
\text { Trade Size (t) }\end{array}$} & \multicolumn{2}{|c|}{$\begin{array}{l}\text { Change in Trade } \\
\text { Size Variability (t) }\end{array}$} & \multicolumn{2}{|c|}{$\begin{array}{c}\text { Change in Number } \\
\text { of Trades (t) }\end{array}$} \\
\hline & $(1)$ & $(2)$ & (3) & (4) & (5) & (6) \\
\hline \multirow[t]{2}{*}{ Avg Trade Ret (t-1) (\%) } & $-0.27 *$ & $-0.54 * * *$ & -0.01 & -0.16 & $-3.96 * * *$ & $-6.17 * * *$ \\
\hline & $(-1.95)$ & $(-5.06)$ & $(-0.11)$ & $(-1.50)$ & $(-12.52)$ & $(-14.82)$ \\
\hline \multirow[t]{2}{*}{$\times \mathrm{I}($ Avg Trade Ret $(\mathrm{t}-1)>0)$} & $0.77 * * *$ & $1.29 * * *$ & $0.54^{* * *}$ & $0.87^{* * *}$ & $7.46^{* * *}$ & $12.37 * * *$ \\
\hline & $(2.74)$ & $(5.08)$ & $(3.52)$ & $(5.18)$ & $(13.81)$ & $(15.43)$ \\
\hline \multirow[t]{2}{*}{ I(Avg Trade Ret $(\mathrm{t}-1)>0)$} & $0.14^{* * *}$ & $0.19 * * *$ & $0.17^{* * *}$ & $0.22 * * *$ & $0.42^{* * *}$ & $0.73^{* * *}$ \\
\hline & $(6.29)$ & $(9.11)$ & $(7.55)$ & (8.37) & $(9.96)$ & $(13.45)$ \\
\hline Calendar FE & Yes & Yes & Yes & Yes & Yes & Yes \\
\hline Week FE & Yes & Yes & Yes & Yes & Yes & Yes \\
\hline Trader FE & No & Yes & No & Yes & No & Yes \\
\hline Obs & 24,815 & 24,815 & 20,699 & 20,699 & 24,815 & 24,815 \\
\hline $\mathrm{R}^{2}$ & 0.011 & 0.034 & 0.022 & 0.025 & 0.038 & 0.064 \\
\hline
\end{tabular}

Panel B: The Discontinuity in the Trading Patterns with Respect to Past Returns, around Zero Past Returns (Two-Week Frequency)

\begin{tabular}{|c|c|c|c|c|c|c|}
\hline \multirow[t]{2}{*}{ Dependent variable: } & \multicolumn{2}{|c|}{$\begin{array}{l}\text { Change in Avg } \\
\text { Trade Size (t) }\end{array}$} & \multicolumn{2}{|c|}{$\begin{array}{l}\text { Change in Trade } \\
\text { Size Variability (t) } \\
\end{array}$} & \multicolumn{2}{|c|}{$\begin{array}{c}\text { Change in Number } \\
\text { of Trades (t) }\end{array}$} \\
\hline & $(1)$ & $(2)$ & $(3)$ & $(4)$ & $(5)$ & $(6)$ \\
\hline I(Avg Trade Ret $(\mathrm{t}-1)>0)$ & $\begin{array}{c}0.10^{* * *} \\
(3.59)\end{array}$ & $\begin{array}{c}0.15^{* * *} \\
(5.84)\end{array}$ & $\begin{array}{c}0.16^{* * *} \\
(7.37)\end{array}$ & $\begin{array}{c}0.18^{* * *} \\
(6.98)\end{array}$ & $\begin{array}{c}0.55^{* * *} \\
(9.33)\end{array}$ & $\begin{array}{l}0.85^{* * * *} \\
(12.51)\end{array}$ \\
\hline 3rd degree polynomial & Yes & Yes & Yes & Yes & Yes & Yes \\
\hline × I(Avg Trade Ret $(\mathrm{t}-1)>0)$ & Yes & Yes & Yes & Yes & Yes & Yes \\
\hline Calendar FE & Yes & Yes & Yes & Yes & Yes & Yes \\
\hline Week FE & Yes & Yes & Yes & Yes & Yes & Yes \\
\hline Trader FE & No & Yes & No & Yes & No & Yes \\
\hline Obs & 24,815 & 24,815 & 20,699 & 20,699 & 24,815 & 24,815 \\
\hline $\mathrm{R}^{2}$ & 0.013 & 0.036 & 0.023 & 0.025 & 0.043 & 0.076 \\
\hline
\end{tabular}




\section{Internet Appendix Table A3. Main Tests without Accounting for Trader Exit}

This table reports results from regressions in which the dependent variable measures change in average trade size or change in trade size variability for trader $i$ from one week to another. In these tests, trader-weeks who exit the sample are simply dropped. Avg Trade $\operatorname{Ret}(t-1)(\%)$ is a continuous variable equal to the return of trader $i$ in the two-week period $t-1$, represented as percentage points. I(Avg Trade $\operatorname{Ret}(t-1)>0)$ is an indicator variable taking a value of 1 when past value-weighted average returns are positive. The change in average trade size, the change in trade size variability, and the change in the number of trades, are represented as fractions. The regressions in Panel B include a third-degree polynomial of returns for the positive and for the negative domains, the coefficients of which are not reported. All regressions include week fixed effects. Trader fixed effects are included where noted. All regressions are OLS regressions. Standard errors are clustered at the trader and week level. $t$-statistics are in parentheses. ${ }^{*}{ }^{* *}$, *** denote significance at the $10 \%, 5 \%$, and $1 \%$ level, respectively.

Panel A: The Slopes of the Trading Patterns around Zero Past Returns (Exiting TraderWeeks Are Dropped)

\begin{tabular}{|c|c|c|c|c|c|c|}
\hline \multirow[t]{2}{*}{ Dependent variable: } & \multicolumn{2}{|c|}{$\begin{array}{c}\text { Change in Avg } \\
\text { Trade Size (t) } \\
\end{array}$} & \multicolumn{2}{|c|}{$\begin{array}{c}\text { Change in Median } \\
\text { Trade Size (t) } \\
\end{array}$} & \multicolumn{2}{|c|}{$\begin{array}{c}\text { Change in Number } \\
\text { of Trades (t) }\end{array}$} \\
\hline & (1) & (2) & (3) & $(4)$ & (5) & (6) \\
\hline Avg Trade Ret (t-1) (\%) & $\begin{array}{c}-0.37 * * \\
(-5.96)\end{array}$ & $\begin{array}{c}-0.55^{* * *} \\
(-8.32)\end{array}$ & $\begin{array}{c}-1.38 * * * \\
(-3.78)\end{array}$ & $\begin{array}{c}-1.82^{* * *} \\
(-4.38)\end{array}$ & $\begin{array}{c}-3.33 * * * \\
(-14.18)\end{array}$ & $\begin{array}{c}-4.98^{* * *} \\
(-17.28)\end{array}$ \\
\hline$\times \mathrm{I}($ Avg Trade Ret $(\mathrm{t}-1)>0)$ & $\begin{array}{c}0.86^{* * * *} \\
(7.09)\end{array}$ & $\begin{array}{l}1.26^{* * * *} \\
(9.30)\end{array}$ & $\begin{array}{l}1.74 * * * \\
(3.78)\end{array}$ & $\begin{array}{l}2.75^{* * *} \\
(5.04)\end{array}$ & $\begin{array}{l}6.02^{* * * *} \\
(13.73)\end{array}$ & $\begin{array}{l}9.63^{* * * *} \\
(18.04)\end{array}$ \\
\hline I(Avg Trade Ret $(\mathrm{t}-1)>0)$ & $\begin{array}{c}0.09 * * * \\
(4.74)\end{array}$ & $\begin{array}{l}0.12^{* * *} \\
(8.10)\end{array}$ & $\begin{array}{c}0.00 \\
(-0.01)\end{array}$ & $\begin{array}{l}0.06^{*} \\
(1.56)\end{array}$ & $\begin{array}{l}0.36^{* * * *} \\
(14.44)\end{array}$ & $\begin{array}{l}0.60^{* * *} \\
(18.72)\end{array}$ \\
\hline Calendar FE & Yes & Yes & Yes & Yes & Yes & Yes \\
\hline Week FE & Yes & Yes & Yes & Yes & Yes & Yes \\
\hline Trader FE & No & Yes & No & Yes & No & Yes \\
\hline Obs & 41,480 & 41,480 & 41,480 & 41,480 & 41,480 & 41,480 \\
\hline $\mathrm{R}^{2}$ & 0.011 & 0.013 & 0.005 & 0.005 & 0.039 & 0.063 \\
\hline
\end{tabular}

Panel B: The Discontinuity in the Trading Patterns around Zero Past Returns (Exiting Trader-Weeks Are Dropped)

\begin{tabular}{|c|c|c|c|c|c|c|}
\hline \multirow[t]{2}{*}{ Dependent variable: } & \multicolumn{2}{|c|}{$\begin{array}{c}\text { Change in Avg } \\
\text { Trade Size (t) }\end{array}$} & \multicolumn{2}{|c|}{$\begin{array}{l}\text { Change in Median } \\
\text { Trade Size (t) }\end{array}$} & \multicolumn{2}{|c|}{$\begin{array}{c}\text { Change in Number } \\
\text { of Trades ( } t)\end{array}$} \\
\hline & $(1)$ & $(2)$ & (3) & (4) & (5) & (6) \\
\hline I(Avg Trade Ret (t-1) >0) & $\begin{array}{c}0.09 * * * \\
(3.87)\end{array}$ & $\begin{array}{l}0.13^{* * *} \\
(6.69)\end{array}$ & $\begin{array}{l}0.10^{*} \\
(2.06)\end{array}$ & $\begin{array}{l}0.17^{* * *} \\
(2.47)\end{array}$ & $\begin{array}{c}0.51^{* * *} \\
(8.78)\end{array}$ & $\begin{array}{l}0.72^{* * *} \\
(11.35)\end{array}$ \\
\hline 3rd degree polynomial & Yes & Yes & Yes & Yes & Yes & Yes \\
\hline × I(Avg Trade Ret $(\mathrm{t}-1)>0)$ & Yes & Yes & Yes & Yes & Yes & Yes \\
\hline Calendar FE & Yes & Yes & Yes & Yes & Yes & Yes \\
\hline Week FE & Yes & Yes & Yes & Yes & Yes & Yes \\
\hline Trader FE & No & Yes & No & Yes & No & Yes \\
\hline Obs & 41,480 & 41,480 & 41,480 & 41,480 & 41,480 & 41,480 \\
\hline $\mathrm{R}^{2}$ & 0.011 & 0.015 & 0.005 & 0.005 & 0.041 & 0.070 \\
\hline
\end{tabular}




\section{Internet Appendix Table A4. Winsorizing the Change in Trade size variability}

This table reports results from regressions in which the dependent variable measures change in trade size variability for trader $i$ in week $t$ relative to week $t-1$. Avg Trade $\operatorname{Ret}(t-1)(\%)$ is a continuous variable equal to the return of trader $i$ in week $t-1$, represented as percentage points. I(Avg Trade $\operatorname{Ret}(t-1)>0)$ is an indicator variable taking a value of 1 when returns in week $t-1$ are positive. The change in trade size variability is represented as a fraction. The dependent variable (change in trade size variability) is winsorized at 5 in Columns (1) to (4), and at 10 in Columns (5) to (8). The regressions in Panel B include a third-degree polynomial of returns for the positive and for the negative domains, the coefficients of which are not reported. All regressions include week fixed effects. Trader fixed effects are included where noted. All regressions are OLS regressions. Standard errors are clustered at the trader and week level. $t$-statistics are in parentheses. *, **, *** denote significance at the $10 \%, 5 \%$, and $1 \%$ level, respectively.

\section{Panel A: The Slopes of the Change in Average Trade Size and the Change in Trade size variability with Respect to Past Returns, around Zero Past Returns}

\begin{tabular}{|c|c|c|c|c|c|c|c|c|}
\hline \multirow{3}{*}{$\begin{array}{l}\text { Dependent variable: } \\
\text { Weeks: }\end{array}$} & \multicolumn{4}{|c|}{$\begin{array}{l}\text { Change in Trade Size Variability (t) } \\
\text { (winsorized at 5) }\end{array}$} & \multicolumn{4}{|c|}{$\begin{array}{l}\text { Change in Trade Size Variability (t) } \\
\text { (winsorized at 10) }\end{array}$} \\
\hline & $\leq 5$ & $\leq 10$ & $\leq 15$ & All & $\leq 5$ & $\leq 10$ & $\leq 15$ & All \\
\hline & (1) & (2) & (3) & (4) & (5) & $(6)$ & (7) & (8) \\
\hline Avg Trade Ret (t-1) (\%) & $\begin{array}{l}-1.23^{*} \\
(-1.92)\end{array}$ & $\begin{array}{c}-0.91^{* * *} \\
(-2.72)\end{array}$ & $\begin{array}{c}-0.71^{* * *} \\
(-2.72)\end{array}$ & $\begin{array}{c}-0.64 * * * \\
(-3.45)\end{array}$ & $\begin{array}{l}-2.69 * * \\
(-2.37)\end{array}$ & $\begin{array}{c}-2.26 * * * \\
(-4.09)\end{array}$ & $\begin{array}{c}-1.71^{* * *} \\
(-3.67)\end{array}$ & $\begin{array}{r}-1.53^{* * *} \\
(-4.73)\end{array}$ \\
\hline$\times \mathrm{I}($ Avg Trade Ret $(\mathrm{t}-1)>0)$ & $\begin{array}{c}4.29 * * * \\
(4.41)\end{array}$ & $\begin{array}{c}3.44 * * * \\
(4.65)\end{array}$ & $\begin{array}{c}2.88^{* * *} \\
(5.43)\end{array}$ & $\begin{array}{c}2.19 * * * \\
(7.20)\end{array}$ & $\begin{array}{c}8.99 * * * \\
(5.24)\end{array}$ & $\begin{array}{c}7.15^{* * *} \\
(5.95)\end{array}$ & $\begin{array}{c}5.81^{* * *} \\
(6.04)\end{array}$ & $\begin{array}{c}4.68 * * * \\
(8.42)\end{array}$ \\
\hline I(Avg Trade Ret $(\mathrm{t}-1)>0)$ & $\begin{array}{c}0.42^{* * * *} \\
(7.83)\end{array}$ & $\begin{array}{c}0.38 * * * \\
(7.34)\end{array}$ & $\begin{array}{c}0.33^{* * *} \\
(9.20)\end{array}$ & $\begin{array}{l}0.32 * * * \\
(12.36)\end{array}$ & $\begin{array}{c}0.64^{* * *} \\
(5.68)\end{array}$ & $\begin{array}{c}0.60 * * * \\
(5.97)\end{array}$ & $\begin{array}{c}0.51^{* * *} \\
(8.28)\end{array}$ & $\begin{array}{c}0.48^{* * *} \\
(11.73)\end{array}$ \\
\hline Calendar FE & Yes & Yes & Yes & Yes & Yes & Yes & Yes & Yes \\
\hline Week FE & Yes & Yes & Yes & Yes & Yes & Yes & Yes & Yes \\
\hline Trader FE & Yes & Yes & Yes & Yes & Yes & Yes & Yes & Yes \\
\hline Obs & 4,247 & 9,378 & 14,396 & 27,361 & 4,247 & 9,378 & 14,396 & 27,631 \\
\hline $\mathrm{R}^{2}$ & 0.055 & 0.036 & 0.028 & 0.023 & 0.054 & 0.034 & 0.0263 & 0.0219 \\
\hline
\end{tabular}

Panel B: The Discontinuity in the Change in Average Trade Size and the Change in Trade size variability with Respect to Past Returns, around Zero Past Returns

\begin{tabular}{|c|c|c|c|c|c|c|c|c|}
\hline \multirow{3}{*}{$\begin{array}{l}\text { Dependent variable: } \\
\text { Weeks: }\end{array}$} & \multicolumn{4}{|c|}{$\begin{array}{l}\text { Change in Trade Size Variability }(\mathrm{t}) \\
\text { (winsorized at 5) }\end{array}$} & \multicolumn{4}{|c|}{$\begin{array}{l}\text { Change in Trade Size Variability (t) } \\
\text { (winsorized at 10) }\end{array}$} \\
\hline & $\leq 5$ & $\leq 10$ & $\leq 15$ & All & $\leq 5$ & $\leq 10$ & $\leq 15$ & All \\
\hline & $(1)$ & $(2)$ & $(3)$ & $(4)$ & $(5)$ & $(6)$ & $(7)$ & $(8)$ \\
\hline I(Avg Trade Ret $(\mathrm{t}-1)>0)$ & $\begin{array}{c}0.39 * * * \\
(3.83)\end{array}$ & $\begin{array}{c}0.38 * * * \\
(3.92)\end{array}$ & $\begin{array}{l}0.31^{* * * *} \\
(4.98)\end{array}$ & $\begin{array}{c}0.27^{* * *} \\
(6.86)\end{array}$ & $\begin{array}{c}0.65^{* * *} \\
(3.42)\end{array}$ & $\begin{array}{c}0.63^{* * * *} \\
(3.50)\end{array}$ & $\begin{array}{c}0.50^{* * *} \\
(4.35)\end{array}$ & $\begin{array}{c}0.42^{* * *} \\
(5.99)\end{array}$ \\
\hline 3rd degree polynomial & Yes & Yes & Yes & Yes & Yes & Yes & Yes & Yes \\
\hline$\times \mathrm{I}($ Avg Trade Ret $(\mathrm{t}-1)>0)$ & Yes & Yes & Yes & Yes & Yes & Yes & Yes & Yes \\
\hline Calendar FE & Yes & Yes & Yes & Yes & Yes & Yes & Yes & Yes \\
\hline Week FE & Yes & Yes & Yes & Yes & Yes & Yes & Yes & Yes \\
\hline Trader FE & Yes & Yes & Yes & Yes & Yes & Yes & Yes & Yes \\
\hline Obs & 4,247 & 9,378 & 14,396 & 27,631 & 4,247 & 9,378 & 14,396 & 27,631 \\
\hline $\mathrm{R}^{2}$ & 0.056 & 0.037 & 0.028 & 0.024 & 0.055 & 0.035 & 0.0265 & 0.0222 \\
\hline
\end{tabular}




\section{Internet Appendix Table A5. Measuring the Discontinuity Using Higher Degree Polynomials}

This table reports results from regressions in which the dependent variable measures the change in average trade size or the change in trade size variability for trader $i$ in week $t$ relative to week $t-1$, or the average trade return in week $t$. Avg Trade Ret $(t-1)(\%)$ is a continuous variable equal to the return of trader $i$ in week $t-1$, represented as percentage points. I(Avg Trade $\operatorname{Ret}(t-1)>0)$ is an indicator variable taking a value of 1 when returns in week $t-1$ are greater than 0 . The change in average trade size, the change in trade size variability, and the change in the number of trades, are represented as fractions. The regressions include a fourth- or fifth-degree polynomial of returns for the positive and for the negative domains, the coefficients of which are not reported. All regressions include week fixed effects and trader fixed effects. All regressions are OLS regressions. Standard errors are clustered at the trader and week level. $t$-statistics are in parentheses. *, **, *** denote significance at the $10 \%, 5 \%$, and $1 \%$ level, respectively.

\begin{tabular}{|c|c|c|c|c|c|c|c|c|}
\hline \multirow{3}{*}{$\begin{array}{l}\text { Dependent variable: } \\
\text { Polynomial degree: }\end{array}$} & \multicolumn{2}{|c|}{$\begin{array}{l}\text { Change in Avg } \\
\text { Trade Size (t) }\end{array}$} & \multicolumn{2}{|c|}{$\begin{array}{l}\text { Change in Trade } \\
\text { Size Variability (t) }\end{array}$} & \multicolumn{2}{|c|}{$\begin{array}{c}\text { Change in Number } \\
\text { of Trades (t) }\end{array}$} & \multicolumn{2}{|c|}{$\begin{array}{l}\text { Average Trade } \\
\text { Return (t) (\%) }\end{array}$} \\
\hline & 4th & 5th & 4th & 5th & 4th & 5th & 4th & 5th \\
\hline & $(1)$ & $(2)$ & $(3)$ & $(4)$ & $(5)$ & $(6)$ & $(7)$ & $(8)$ \\
\hline I(Avg Trade Ret $(\mathrm{t}-1)>0)$ & $\begin{array}{c}0.14^{* * *} \\
(6.47)\end{array}$ & $\begin{array}{c}0.15^{* * *} \\
(5.96)\end{array}$ & $\begin{array}{c}0.15^{* * * *} \\
(7.16)\end{array}$ & $\begin{array}{c}0.13^{* * *} \\
(6.48)\end{array}$ & $\begin{array}{l}0.70^{* * *} \\
(-11.35)\end{array}$ & $\begin{array}{l}0.68^{* * *} \\
(-11.19)\end{array}$ & $\begin{array}{l}-0.01^{* *} \\
(-2.05)\end{array}$ & $\begin{array}{l}-0.01^{* *} \\
(-2.27)\end{array}$ \\
\hline Xth degree polynomial & Yes & Yes & Yes & Yes & Yes & Yes & Yes & Yes \\
\hline × I(Avg Trade Ret $(\mathrm{t}-1)>0)$ & Yes & Yes & Yes & Yes & Yes & Yes & Yes & Yes \\
\hline Calendar FE & Yes & Yes & Yes & Yes & Yes & Yes & Yes & Yes \\
\hline Week FE & Yes & Yes & Yes & Yes & Yes & Yes & Yes & Yes \\
\hline Trader FE & Yes & Yes & Yes & Yes & Yes & Yes & Yes & Yes \\
\hline Obs & 42,880 & 42,880 & 34,785 & 34,785 & 42,880 & 42,880 & 41,480 & 41,480 \\
\hline $\mathrm{R}^{2}$ & 0.015 & 0.016 & 0.026 & 0.026 & 0.063 & 0.064 & 0.015 & 0.015 \\
\hline
\end{tabular}




\section{Internet Appendix Table A6. Estimation Using WLS}

This table reports results from regressions in which the dependent variable measures the change in average trade size, the change in trade size variability for trader $i$ in week $t$ relative to week $t-1$, or the average trade return in week $t$. Avg Trade $\operatorname{Ret}(t-1)(\%)$ is a continuous variable equal to the return of trader $i$ in week $t-1$, represented as percentage points. I(Avg Trade $\operatorname{Ret}(t-1)>0)$ is an indicator variable taking a value of 1 when returns in week $t-1$ are greater than 0 . The change in average trade size, the change in trade size variability, and the change in the number of trades, are represented as fractions. The regressions in Panel B include a third-degree polynomial of returns for the positive and for the negative domains, the coefficients of which are not reported. All regressions include week fixed effects, and trader fixed effects are included where noted. All regressions are weighted least squares (WLS) regressions. Standard errors are clustered at the trader and week level. $t$-statistics are in parentheses. ${ }^{*}, * *, * * *$ denote significance at the $10 \%, 5 \%$, and $1 \%$ level, respectively.

Panel A: The Slopes of the Trading Patterns with Respect to Past Returns, around Zero Past Returns

\begin{tabular}{|c|c|c|c|c|c|c|c|c|}
\hline \multirow[t]{2}{*}{ Dependent variable: } & \multicolumn{2}{|c|}{$\begin{array}{c}\text { Change in Avg } \\
\text { Trade Size (t) }\end{array}$} & \multicolumn{2}{|c|}{$\begin{array}{l}\text { Change in Trade } \\
\text { Size Variability (t) }\end{array}$} & \multicolumn{2}{|c|}{$\begin{array}{c}\text { Change in Number } \\
\text { of Trades ( } \mathrm{t})\end{array}$} & \multicolumn{2}{|c|}{$\begin{array}{c}\text { Average Trade } \\
\text { Return (t) (\%) }\end{array}$} \\
\hline & (1) & $(2)$ & (3) & (4) & (5) & (6) & (7) & (8) \\
\hline Avg Trade Ret (t-1) (\%) & $\begin{array}{c}-0.95^{* * *} \\
(-5.07)\end{array}$ & $\begin{array}{l}-0.62^{* * *} \\
(-4.03)\end{array}$ & $\begin{array}{l}-0.29 * \\
(-1.76)\end{array}$ & $\begin{array}{c}-0.12 \\
(-0.81)\end{array}$ & $\begin{array}{l}-6.43 * * * \\
(-14.22)\end{array}$ & $\begin{array}{c}-9.32 * * * \\
(18.48)\end{array}$ & $\begin{array}{c}-0.09^{* * * *} \\
(-4.66)\end{array}$ & $\begin{array}{l}0.03 * * \\
(2.29)\end{array}$ \\
\hline$\times \mathrm{I}($ Avg Trade Ret $(\mathrm{t}-1)>0)$ & $\begin{array}{l}1.76^{* * *} \\
(5.22)\end{array}$ & $\begin{array}{l}1.07^{* * *} \\
(4.39)\end{array}$ & $\begin{array}{c}0.99 * * * \\
(3.28)\end{array}$ & $\begin{array}{l}0.46^{* *} \\
(2.02)\end{array}$ & $\begin{array}{l}0.32^{* * *} \\
(17.59)\end{array}$ & $\begin{array}{c}19.00^{* * *} \\
(21.87)\end{array}$ & $\begin{array}{c}-0.03 \\
(-0.66)\end{array}$ & $\begin{array}{c}-0.11^{* * *} \\
(-2.92)\end{array}$ \\
\hline I(Avg Trade Ret $(\mathrm{t}-1)>0)$ & $\begin{array}{l}0.19 * * * \\
(10.66)\end{array}$ & $\begin{array}{c}0.15^{* * *} \\
(6.92)\end{array}$ & $\begin{array}{l}0.23^{* * *} \\
(11.19)\end{array}$ & $\begin{array}{c}0.19 * * * \\
(9.53)\end{array}$ & $\begin{array}{c}0.32^{* * *} \\
(7.12)\end{array}$ & $\begin{array}{l}0.58^{* * *} \\
(12.30)\end{array}$ & $\begin{array}{c}0.00 \\
(1.15)\end{array}$ & $\begin{array}{l}0.00 * * \\
(2.27)\end{array}$ \\
\hline Calendar FE & Yes & Yes & Yes & Yes & Yes & Yes & Yes & Yes \\
\hline Week FE & Yes & Yes & Yes & Yes & Yes & Yes & Yes & Yes \\
\hline Trader FE & No & Yes & No & Yes & No & Yes & No & Yes \\
\hline Obs & 42,880 & 42,880 & 34,785 & 34,785 & 42,880 & 42,880 & 41,480 & 41,480 \\
\hline $\mathrm{R}^{2}$ & 0.027 & 0.042 & 0.034 & 0.078 & 0.104 & 0.084 & 0.023 & 0.045 \\
\hline
\end{tabular}

Panel B: The Discontinuity in the Trading Patterns with Respect to Past Returns, around Zero Past Returns

\begin{tabular}{|c|c|c|c|c|c|c|c|c|}
\hline \multirow[t]{2}{*}{ Dependent variable: } & \multicolumn{2}{|c|}{$\begin{array}{c}\text { Change in Avg } \\
\text { Trade Size (t) }\end{array}$} & \multicolumn{2}{|c|}{$\begin{array}{l}\text { Change in Trade } \\
\text { Size Variability (t) }\end{array}$} & \multicolumn{2}{|c|}{$\begin{array}{c}\text { Change in Number } \\
\text { of Trades (t) }\end{array}$} & \multicolumn{2}{|c|}{$\begin{array}{l}\text { Average Trade } \\
\text { Return }(\mathrm{t})(\%)\end{array}$} \\
\hline & (1) & $(2)$ & (3) & (4) & (5) & (6) & $(7)$ & $(8)$ \\
\hline I(Avg Trade Ret $(t-1)>0)$ & $\begin{array}{c}0.18^{* * *} \\
(7.62)\end{array}$ & $\begin{array}{l}0.15^{* * *} \\
(4.45)\end{array}$ & $\begin{array}{l}0.17 * * * \\
(5.87)\end{array}$ & $\begin{array}{c}0.16^{* * *} \\
(5.57)\end{array}$ & $\begin{array}{c}0.41^{* * *} \\
(6.84)\end{array}$ & $\begin{array}{l}0.61^{* * *} \\
(9.84)\end{array}$ & $\begin{array}{c}-0.0028^{* * *} \\
(-1.28)\end{array}$ & $\begin{array}{c}-0.0040^{* * *} \\
(-1.81)\end{array}$ \\
\hline 3rd degree polynomial & Yes & Yes & Yes & Yes & Yes & Yes & Yes & Yes \\
\hline$\times \mathrm{I}($ Avg Trade Ret $(\mathrm{t}-1)>0)$ & Yes & Yes & Yes & Yes & Yes & Yes & Yes & Yes \\
\hline Calendar FE & Yes & Yes & Yes & Yes & Yes & Yes & Yes & Yes \\
\hline Week FE & Yes & Yes & Yes & Yes & Yes & Yes & Yes & Yes \\
\hline Trader FE & No & Yes & No & Yes & No & Yes & No & Yes \\
\hline Obs & 42,880 & 42,880 & 34,785 & 34,785 & 42,880 & 42,880 & 41,480 & 41,480 \\
\hline $\mathrm{R}^{2}$ & 0.030 & 0.044 & 0.035 & 0.078 & 0.106 & 0.092 & 0.024 & 0.047 \\
\hline
\end{tabular}




\section{Internet Appendix Table A7. Falsification Tests: Testing Slope and Discontinuity at Other Values}

This table reports results from regressions in which the dependent variable measures the change in average trade size or the change in trade size variability for trader $i$ in the week $t$ relative to week $t-1$. Avg $\operatorname{Trade} \operatorname{Ret}(t-1)(\%)$ is a continuous variable equal to the return of trader $i$ in week $t-1$, represented as percentage points. I(Avg Trade Ret( $t$ 1) $>x$ ) is an indicator variable taking a value of 1 when returns in week $t-1$ are greater than $0+/$ - the specified number of standard deviations. The change in average trade size, the change in trade size variability, and the change in the number of trades, are represented as fractions. The regressions in Panels D to F include a third-degree polynomial of returns for the positive and for the negative domains, the coefficients of which are not reported. All regressions include week fixed effects, and trader fixed effects are included where noted. All regressions are OLS regressions. Standard errors are clustered at the trader and week level. $t$-statistics are in parentheses. *, **, *** denote significance at the $10 \%, 5 \%$, and $1 \%$ level, respectively.

\section{Panel A: Slopes of the Change in Average Trade Size around Non-Zero Returns}

\begin{tabular}{|c|c|c|c|c|c|c|c|c|c|}
\hline \multirow[t]{3}{*}{ Dependent variable: } & \multicolumn{9}{|c|}{ Change in Avg Trade Size (t) } \\
\hline & -2 std & $-1.5 \mathrm{std}$ & $-1 \mathrm{std}$ & $-0.5 \mathrm{std}$ & $0 \mathrm{std}$ & $+0.5 \mathrm{std}$ & +1 std & $+1.5 \mathrm{std}$ & +2 std \\
\hline & (1) & $(2)$ & (3) & (4) & (5) & (6) & $(7)$ & $(8)$ & $(9)$ \\
\hline \multirow[t]{2}{*}{ Avg Trade Ret (t-1) (\%) } & 0.08 & 0.06 & -0.01 & $-0.10^{*}$ & $-0.31^{* * *}$ & -0.01 & $0.12^{* * *}$ & $0.15^{* * *}$ & $0.17^{* * *}$ \\
\hline & $(0.38)$ & $(0.44)$ & $(-0.12)$ & $(-1.63)$ & $(-5.18)$ & $(-0.18)$ & $(2.69)$ & (3.75) & $(4.31)$ \\
\hline \multirow[t]{2}{*}{$\times \mathrm{I}($ Avg Trade Ret $(\mathrm{t}-1)>\mathrm{x})$} & $0.39 *$ & $0.51^{* * *}$ & $0.71 * * *$ & $0.95^{* * *}$ & $0.84^{* * *}$ & $0.26^{*}$ & 0.20 & 0.39 & 0.53 \\
\hline & $(1.86)$ & (3.73) & $(6.55)$ & $(8.22)$ & (6.55) & $(1.86)$ & $(1.17)$ & (1.26) & $(1.23)$ \\
\hline \multirow[t]{2}{*}{ I(Avg Trade Ret (t-1) > x) } & -0.04 & -0.05 & -0.03 & -0.01 & $0.13^{* * *}$ & $0.13^{* * *}$ & 0.06 & -0.03 & -0.11 \\
\hline & $(-0.40)$ & $(-0.77)$ & $(-0.75)$ & $(-0.30)$ & $(9.10)$ & $(4.88)$ & (1.13) & $(-0.27)$ & $(-0.61)$ \\
\hline Calendar FE & Yes & Yes & Yes & Yes & Yes & Yes & Yes & Yes & Yes \\
\hline Week FE & Yes & Yes & Yes & Yes & Yes & Yes & Yes & Yes & Yes \\
\hline Trader FE & Yes & Yes & Yes & Yes & Yes & Yes & Yes & Yes & Yes \\
\hline Obs & 42,880 & 42,880 & 42,880 & 42,880 & 42,880 & 42,880 & 42,880 & 42,880 & 42,880 \\
\hline $\mathrm{R}^{2}$ & 0.010 & 0.010 & 0.011 & 0.012 & 0.014 & 0.010 & 0.009 & 0.009 & 0.009 \\
\hline
\end{tabular}

Panel B: Slopes of the Change in Trade size variability around Non-Zero Returns 


\begin{tabular}{|c|c|c|c|c|c|c|c|c|c|}
\hline \multirow[t]{3}{*}{ Dependent variable: } & \multicolumn{9}{|c|}{ Change in Trade Size Variability (t) } \\
\hline & -2 std & $-1.5 \mathrm{std}$ & -1 std & $-0.5 \mathrm{std}$ & 0 std & $+0.5 \mathrm{std}$ & $+1 \mathrm{std}$ & $+1.5 \mathrm{std}$ & +2 std \\
\hline & $(1)$ & $(2)$ & $(3)$ & $(4)$ & $(5)$ & $(6)$ & $(7)$ & $(8)$ & $(9)$ \\
\hline Avg Trade Ret (t-1) (\%) & $\begin{array}{c}-0.01 \\
(-0.04)\end{array}$ & $\begin{array}{c}-0.23 \\
(-0.91)\end{array}$ & $\begin{array}{l}-0.32 * \\
(-1.82)\end{array}$ & $\begin{array}{c}-0.32 * * * \\
(-2.58)\end{array}$ & $\begin{array}{l}-0.17^{*} \\
(-1.81)\end{array}$ & $\begin{array}{c}0.41^{* * *} \\
(5.13)\end{array}$ & $\begin{array}{c}0.53 * * * \\
(6.85)\end{array}$ & $\begin{array}{c}0.55^{* * *} \\
(7.41)\end{array}$ & $\begin{array}{c}0.58^{* * * *} \\
(8.26)\end{array}$ \\
\hline × I $($ Avg Trade Ret $(\mathrm{t}-1)>\mathrm{x})$ & $\begin{array}{c}1.05^{* * *} \\
(3.11)\end{array}$ & $\begin{array}{c}1.36^{* * *} \\
(4.99)\end{array}$ & $\begin{array}{c}1.57^{* * * *} \\
(7.32)\end{array}$ & $\begin{array}{c}1.58 * * * \\
(8.95)\end{array}$ & $\begin{array}{c}0.72^{* * *} \\
(4.29)\end{array}$ & $\begin{array}{c}-0.10 \\
(-0.49)\end{array}$ & $\begin{array}{c}-0.25 \\
(-0.92)\end{array}$ & $\begin{array}{c}-0.63 \\
(-1.39)\end{array}$ & $\begin{array}{c}-0.32 \\
(-0.42)\end{array}$ \\
\hline I(Avg Trade Ret $(\mathrm{t}-1)>\mathrm{x})$ & $\begin{array}{c}0.01 \\
(0.10)\end{array}$ & $\begin{array}{c}0.12 \\
(1.33)\end{array}$ & $\begin{array}{c}0.16^{* * *} \\
(3.04)\end{array}$ & $\begin{array}{c}0.16^{* * *} \\
(6.43)\end{array}$ & $\begin{array}{c}0.22 * * * \\
(15.39)\end{array}$ & $\begin{array}{c}0.15^{* * *} \\
(4.20)\end{array}$ & $\begin{array}{l}0.13^{*} \\
(1.90)\end{array}$ & $\begin{array}{c}0.28 \\
(1.61)\end{array}$ & $\begin{array}{c}0.13 \\
(0.43)\end{array}$ \\
\hline Calendar FE & Yes & Yes & Yes & Yes & Yes & Yes & Yes & Yes & Yes \\
\hline Week FE & Yes & Yes & Yes & Yes & Yes & Yes & Yes & Yes & Yes \\
\hline Trader FE & Yes & Yes & Yes & Yes & Yes & Yes & Yes & Yes & Yes \\
\hline Obs & 34,785 & 34,785 & 34,785 & 34,785 & 34,785 & 34,785 & 34,785 & 34,785 & 34,785 \\
\hline $\mathrm{R}^{2}$ & 0.020 & 0.020 & 0.021 & 0.021 & 0.025 & 0.018 & 0.017 & 0.017 & 0.017 \\
\hline
\end{tabular}


Internet Appendix Table A7. Falsification Tests: Testing Slope and Discontinuity at Other Values (Cont.)

Panel C: Slopes of the Change in the Number of Trades around Non-Zero Returns

\begin{tabular}{|c|c|c|c|c|c|c|c|c|c|}
\hline \multirow[t]{3}{*}{ Dependent variable: } & \multicolumn{9}{|c|}{ Change in Number of Trades $(t)$} \\
\hline & -2 std & $-1.5 \mathrm{std}$ & -1 std & $-0.5 \mathrm{std}$ & 0 std & $+0.5 \mathrm{std}$ & +1 std & $+1.5 \mathrm{std}$ & +2 std \\
\hline & (1) & (2) & (3) & (4) & (5) & (6) & $(7)$ & (8) & (9) \\
\hline \multirow[t]{2}{*}{ Avg Trade Ret (t-1) (\%) } & $-2.23 * * *$ & $-2.35 * * *$ & $-2.03 * * *$ & $-2.82 * * *$ & $-4.29 * * *$ & $-2.60 * * *$ & $-1.82 * * *$ & $-1.41^{* * *}$ & $-1.13^{* * *}$ \\
\hline & $(-3.62)$ & $(-5.07)$ & $(-6.09)$ & $(-11.51)$ & $(-16.41)$ & $(-12.19)$ & $(-9.56)$ & $(-7.57)$ & $(-6.32)$ \\
\hline \multirow[t]{2}{*}{$\times \mathrm{I}($ Avg Trade Ret $(\mathrm{t}-1)>\mathrm{x})$} & $4.09^{* * *}$ & $4.88^{* * *}$ & $5.85^{* * *}$ & $8.11^{* * *}$ & $8.50^{* * *}$ & $5.61^{* * *}$ & $4.66^{* * *}$ & $4.07^{* * *}$ & $5.01^{* * *}$ \\
\hline & $(6.41)$ & $(9.92)$ & (14.73) & (18.33) & (16.85) & (11.17) & $(7.23)$ & $(4.88)$ & $(2.75)$ \\
\hline \multirow[t]{2}{*}{ I (Avg Trade Ret $(\mathrm{t}-1)>\mathrm{x})$} & 0.00 & -0.01 & $-0.31 * *$ & $-0.15 * *$ & $0.61^{* * *}$ & $0.47^{* * *}$ & $0.33^{* *}$ & 0.29 & -0.32 \\
\hline & $(0.01)$ & $(-0.03)$ & $(-2.59)$ & $(-2.50)$ & (19.89) & $(7.49)$ & $(2.02)$ & $(1.00)$ & $(-0.43)$ \\
\hline Calendar FE & Yes & Yes & Yes & Yes & Yes & Yes & Yes & Yes & Yes \\
\hline Week FE & Yes & Yes & Yes & Yes & Yes & Yes & Yes & Yes & Yes \\
\hline Trader FE & Yes & Yes & Yes & Yes & Yes & Yes & Yes & Yes & Yes \\
\hline Obs & 42,880 & 42,880 & 42,880 & 42,880 & 42,880 & 42,880 & 42,880 & 42,880 & 42,880 \\
\hline $\mathrm{R}^{2}$ & 0.027 & 0.031 & 0.042 & 0.050 & 0.056 & 0.039 & 0.030 & 0.026 & 0.022 \\
\hline
\end{tabular}

Panel D: Discontinuity in the Change in Average Trade Size around Non-Zero Returns

\begin{tabular}{lccccccccc}
\hline Dependent variable: & \multicolumn{8}{c}{ Change in Avg Trade Size (t) } \\
\cline { 2 - 10 } & -2 std & -1.5 std & -1 std & -0.5 std & 0 std & +0.5 std & +1 std & +1.5 std & +2 std \\
\cline { 2 - 10 } & $(1)$ & $(2)$ & $(3)$ & $(4)$ & $(5)$ & $(6)$ & $(7)$ & $(8)$ & $(9)$ \\
\hline I(Avg Trade Ret (t-1) $>\mathrm{x})$ & $-9.41^{*}$ & $-1.71^{* *}$ & -0.24 & -0.01 & $0.12^{* * *}$ & -0.06 & $1.02^{* *}$ & -1.59 & $25.97^{*}$ \\
& $(-5.04)$ & $(-2.46)$ & $(-0.97)$ & $(-0.19)$ & $(6.48)$ & $(-0.51)$ & $(2.13)$ & $(-0.43)$ & $(1.84)$ \\
& & & & & & & & & \\
3rd degree polynomial & Yes & Yes & Yes & Yes & Yes & Yes & Yes & Yes & Yes \\
$\quad$ I I(Avg Trade Ret (t-1) $>$ x) & Yes & Yes & Yes & Yes & Yes & Yes & Yes & Yes & Yes \\
Calendar FE & Yes & Yes & Yes & Yes & Yes & Yes & Yes & Yes & Yes \\
Week FE & Yes & Yes & Yes & Yes & Yes & Yes & Yes & Yes & Yes \\
Trader FE & Yes & Yes & Yes & Yes & Yes & Yes & Yes & Yes & Yes \\
& & & & & & & & & \\
Obs & & & & & & & & & \\
$\mathrm{R}^{2}$ & 42,880 & 42,880 & 42,880 & 42,880 & 42,880 & 42,880 & 42,880 & 42,880 & 42,880 \\
& 0.0126 & 0.0119 & 0.0117 & 0.013 & 0.015 & 0.0126 & 0.0128 & 0.0116 & 0.0109 \\
\hline
\end{tabular}


Internet Appendix Table A7. Falsification Tests: Testing Slope and Discontinuity at Other Values (Cont.)

Panel E: Discontinuity in the Change in Trade size variability around Non-Zero Returns

\begin{tabular}{lccccccccc}
\hline Dependent variable: & \multicolumn{7}{c}{ Change in Trade Size Variability (t) } \\
\cline { 2 - 10 } & -2 std & -1.5 std & -1 std & -0.5 std & 0 std & +0.5 std & +1 std & +1.5 std & +2 std \\
\cline { 2 - 10 } & $(1)$ & $(2)$ & $(3)$ & $(4)$ & $(5)$ & $(6)$ & $(7)$ & $(8)$ & $(9)$ \\
\hline I(Avg Trade Ret $(\mathrm{t}-1)>\mathrm{x})$ & 3.40 & $1.61^{*}$ & 0.53 & $0.16^{*}$ & $0.17^{* * *}$ & 0.19 & 0.46 & 3.39 & -8.93 \\
& $(1.16)$ & $(1.65)$ & $(1.51)$ & $(1.91)$ & $(9.29)$ & $(0.99)$ & $(0.45)$ & $(1.02)$ & $(-0.36)$ \\
& & & & & & & & & \\
3rd degree polynomial & Yes & Yes & Yes & Yes & Yes & Yes & Yes & Yes & Yes \\
$\quad$ I I(Avg Trade Ret (t-1) > x) & Yes & Yes & Yes & Yes & Yes & Yes & Yes & Yes & Yes \\
Calendar FE & Yes & Yes & Yes & Yes & Yes & Yes & Yes & Yes & Yes \\
Week FE & Yes & Yes & Yes & Yes & Yes & Yes & Yes & Yes & Yes \\
Trader FE & Yes & Yes & Yes & Yes & Yes & Yes & Yes & Yes & Yes \\
& & & & & & & & & \\
Obs & 34,785 & 34,785 & 34,785 & 34,785 & 34,785 & 34,785 & 34,785 & 34,785 & 34,785 \\
$\mathrm{R}^{2}$ & 0.022 & 0.022 & 0.022 & 0.023 & 0.025 & 0.023 & 0.022 & 0.021 & 0.020 \\
\hline
\end{tabular}

Panel F: Discontinuity in the Change in the Number of Trades around Non-Zero Returns

\begin{tabular}{|c|c|c|c|c|c|c|c|c|c|}
\hline \multirow[t]{3}{*}{ Dependent variable: } & \multicolumn{9}{|c|}{ Change in Number of Trades ( $\mathrm{t}$ ) } \\
\hline & $-2 \mathrm{std}$ & $-1.5 \mathrm{std}$ & $-1 \mathrm{std}$ & $-0.5 \mathrm{std}$ & 0 std & $+0.5 \mathrm{std}$ & $+1 \mathrm{std}$ & $+1.5 \mathrm{std}$ & $+2 \mathrm{std}$ \\
\hline & (1) & (2) & (3) & (4) & (5) & (6) & (7) & (8) & (9) \\
\hline I(Avg Trade Ret $(\mathrm{t}-1)>\mathrm{x})$ & $\begin{array}{c}-25.09 * * * \\
(-5.60)\end{array}$ & $\begin{array}{c}-5.82^{* * * *} \\
(-3.48)\end{array}$ & $\begin{array}{c}-2.32 * * * \\
(-2.83)\end{array}$ & $\begin{array}{c}0.20 \\
(1.06)\end{array}$ & $\begin{array}{c}0.69^{* * *} \\
(10.91)\end{array}$ & $\begin{array}{c}0.15 \\
(0.39)\end{array}$ & $\begin{array}{c}0.32 \\
(0.18)\end{array}$ & $\begin{array}{l}13.46 \\
(1.62)\end{array}$ & $\begin{array}{c}9.38 \\
(0.16)\end{array}$ \\
\hline 3rd degree polynomial & Yes & Yes & Yes & Yes & Yes & Yes & Yes & Yes & Yes \\
\hline$\times$ I $($ Avg Trade Ret $(\mathrm{t}-1)>\mathrm{x})$ & Yes & Yes & Yes & Yes & Yes & Yes & Yes & Yes & Yes \\
\hline Calendar FE & Yes & Yes & Yes & Yes & Yes & Yes & Yes & Yes & Yes \\
\hline Week FE & Yes & Yes & Yes & Yes & Yes & Yes & Yes & Yes & Yes \\
\hline Trader FE & Yes & Yes & Yes & Yes & Yes & Yes & Yes & Yes & Yes \\
\hline Obs & 42,880 & 42,880 & 42,880 & 42,880 & 42,880 & 42,880 & 42,880 & 42,880 & 42,880 \\
\hline $\mathrm{R}^{2}$ & 0.0469 & 0.0492 & 0.0493 & 0.053 & 0.062 & 0.0474 & 0.0471 & 0.0456 & 0.0431 \\
\hline
\end{tabular}




\section{Internet Appendix Table A8. Regression Discontinuity Design without High-Order Polynomials}

This table reports results from regressions in which the dependent variable measures the change in average trade size, the change in trade size variability for trader $i$ in week $t$ relative to week $t-1$, or the average trade return in week $t$. Avg Trade $\operatorname{Ret}(t-1)(\%)$ is a continuous variable equal to the return of trader $i$ in week $t-1$, represented as percentage points. I(Avg Trade $\operatorname{Ret}(t-1)>0)$ is an indicator variable taking a value of 1 when returns in week $t-1$ are greater than 0 . The change in average trade size, the change in trade size variability, and the change in the number of trades, are represented as fractions. The sample in this regression is limited to $+/-0.5$ standard deviations $(+/-0.07 \%)$ around the origin. All regressions include week fixed effects, and trader fixed effects are included where noted. All regressions are OLS regressions. Standard errors are clustered at the trader and week level. $t$-statistics are in parentheses. *, **, $* * *$ denote significance at the $10 \%, 5 \%$, and $1 \%$ level, respectively.

\begin{tabular}{|c|c|c|c|c|c|c|c|c|}
\hline \multirow[t]{2}{*}{ Dependent variable: } & \multicolumn{2}{|c|}{$\begin{array}{c}\text { Change in Avg } \\
\text { Trade Size (t) }\end{array}$} & \multicolumn{2}{|c|}{$\begin{array}{l}\text { Change in Trade } \\
\text { Size Variability (t) }\end{array}$} & \multicolumn{2}{|c|}{$\begin{array}{c}\text { Change in Number } \\
\text { of Trades (t) }\end{array}$} & \multicolumn{2}{|c|}{$\begin{array}{l}\text { Average Trade } \\
\text { Return (t) (\%) }\end{array}$} \\
\hline & $(1)$ & $(2)$ & (3) & $(4)$ & $(5)$ & $(6)$ & $(7)$ & $(8)$ \\
\hline Avg Trade Ret (t-1) (\%) & $\begin{array}{l}-0.92 * * \\
(-1.99)\end{array}$ & $\begin{array}{l}-1.28^{* *} \\
(-2.34)\end{array}$ & $\begin{array}{l}0.99 * \\
(1.91)\end{array}$ & $\begin{array}{l}1.06^{* *} \\
(2.14)\end{array}$ & $\begin{array}{c}-4.69 * * * \\
(-4.39)\end{array}$ & $\begin{array}{c}-8.76^{* * * *} \\
(-7.25)\end{array}$ & $\begin{array}{c}0.17^{* * *} \\
(3.35)\end{array}$ & $\begin{array}{c}0.04 \\
(0.55)\end{array}$ \\
\hline$\times \mathrm{I}($ Avg Trade Ret $(\mathrm{t}-1)>0)$ & $\begin{array}{c}1.93 * * * \\
(3.13)\end{array}$ & $\begin{array}{c}2.41^{* * *} \\
(3.35)\end{array}$ & $\begin{array}{c}-0.95 \\
(-1.27)\end{array}$ & $\begin{array}{c}-0.52 \\
(-0.70)\end{array}$ & $\begin{array}{c}6.68 * * * \\
(4.81)\end{array}$ & $\begin{array}{c}16.71 * * * \\
(9.61)\end{array}$ & $\begin{array}{c}-0.09 \\
(-0.95)\end{array}$ & $\begin{array}{c}-0.07 \\
(-0.70)\end{array}$ \\
\hline I(Avg Trade Ret $(\mathrm{t}-1)>0)$ & $\begin{array}{c}0.11^{* * *} \\
(4.56)\end{array}$ & $\begin{array}{c}0.14^{* * * *} \\
(6.20)\end{array}$ & $\begin{array}{c}0.16^{* * * *} \\
(7.32)\end{array}$ & $\begin{array}{c}0.17 * * * \\
(8.84)\end{array}$ & $\begin{array}{c}0.48 * * * \\
(7.64)\end{array}$ & $\begin{array}{c}0.60 * * * \\
(9.62)\end{array}$ & $\begin{array}{l}-0.0016 \\
(-0.63)\end{array}$ & $\begin{array}{l}-0.0031 \\
(-1.25)\end{array}$ \\
\hline Calendar FE & Yes & Yes & Yes & Yes & Yes & Yes & Yes & Yes \\
\hline Week FE & Yes & Yes & Yes & Yes & Yes & Yes & Yes & Yes \\
\hline Trader FE & No & Yes & No & Yes & No & Yes & No & Yes \\
\hline Obs & 29,497 & 29,497 & 25,525 & 25,525 & 29,497 & 29,497 & 28,813 & 28,813 \\
\hline $\mathrm{R}^{2}$ & 0.011 & 0.013 & 0.022 & 0.023 & 0.026 & 0.036 & 0.011 & 0.013 \\
\hline
\end{tabular}

